\title{
Revisão taxonômica de Matayba sect. Matayba (Sapindaceae, Cupanieae)
}

\author{
Taxonomic revision of Matayba sect. Matayba (Sapindaceae, Cupanieae)
}

Rubens Luiz Gayoso Coelho ${ }^{1,2}$, Vinicius Castro Souza ${ }^{1,2}$, María Silvia Ferrucci ${ }^{3}$ \& Thiago Bevilacqua Flores ${ }^{1,2}$

\begin{abstract}
Resumo
Matayba contêm cerca de 50 espécies de arbustos ou árvores distribuídas desde o México até o norte da Argentina e divididas em quatro seções. No Brasil estão presentes 30 espécies e 17 delas são endêmicas. Matayba sect. Matayba tem o maior número de espécies e ocorre apenas na América do Sul. No Brasil essa seção está representada predominantemente fora da região Amazônica, com exceção de M. guianensis que é amplamente distribuída na América do Sul. A presente revisão taxonômica das espécies de Matayba sect. Matayba, inclui descrições, reavaliação nomenclatural e tipificação, delimitação dos táxons, chave de identificação e ilustrações. Os principais caracteres diagnósticos desta seção são o número e forma dos folíolos, os padrões da nervação e a posição e proeminência das domácias. Nas flores, o indumento das sépalas, pétalas e filetes é o caráter mais usado. Um total de 17 espécies nessa seção são reconhecidas. Uma espécie foi excluída, 20 lectótipos e um neótipo são designados, dois nomes de espécies e 10 de formas e subformas são posicionados em sinonímia e novos dados de distribuição para diversas espécies no Brasil foram registrados. Palavras-chave: Matayba sect. Matayba, Sapindaceae, Cupanieae, revisão taxonômica.
\end{abstract}

\begin{abstract}
Matayba contains around 50 species of shrubs or trees, distributed from Mexico to northern Argentina and it is divided into four sections. In Brazil there are 30 species, 17 of them endemic. Matayba sect. Matayba is the largest section of the genus in number of species and occurs only in South America. In Brazil, this section is mainly found outside the Amazon region, with the exception of M. guianensis wich is widely distributed throughout South America. The present taxonomic revision of Matayba sect. Matayba includes descriptions, nomenclatural and classification reassessment, taxa delimitation, identification keys and illustrations. The main diagnostic characters for this section are the number and shape of the leaflets, the venation patterns and the prominence and position of the domatia. In the flowers, the most useful features are the indument on sepals, petals and filaments, both of diagnostic and taxonomic importance. A total of 17 species are recognized in this section. One species was excluded, 20 lectotypes and one neotype are designated, two species names and 10 forms and subforms are placed in synonymy, and new distributional records for several species in Brazil are registered.
\end{abstract}

Key words: Matayba sect. Matayba, Sapindaceae, Cupanieae, taxonomic revision.

\section{Introdução}

No sistema de Radlkofer $(1879,1900,1934)$, Sapindaceae é constituída por duas subfamílias e 14 tribos. Atualmente, a família possui cerca de 140 gêneros e 1900 espécies, na maioria ocorrendo em regiões tropicais e subtropicais, com poucos membros em áreas temperadas. Esses gêneros estão atualmente divididos em quatro subfamílias, Xanthoceroideae, Hippocastanoideae, Dodonaeoideae e Sapindoideae (Buerki et al. 2009; Acevedo-Rodríguez et al. 2011). No Brasil, a família é representada por 28 gêneros e 418 espécies presentes na grande maioria das formações vegetacionais do país (BFG 2015).

\footnotetext{
${ }^{1}$ Universidade Estadual de Campinas, Inst. Biologia, C.P. 6109, 13083-970, Campinas, SP, Brasil.

${ }^{2}$ Universidade de São Paulo, Escola Superior de Agricultura “Luiz de Queiroz”, Depto. Ciências Biológicas, C.P. 9, 13418-900, Piracicaba, SP, Brasil. vcsouza@usp.br

${ }^{3}$ Instituto de Botánica del Nordeste, C.C. 209, 3400, Corrientes, Corrientes, Argentina. msferrucci@yahoo.com.ar

${ }^{4}$ Autor para correspondência: rubenslgc@gmail.com
} 
O gênero Matayba Aubl. é um dos maiores em número de espécies na tribo Cupanieae (Radlkofer 1879, 1934), com cerca de 50 espécies restritas à região neotropical e ocorrendo desde o México até o norte da Argentina (Acevedo-Rodríguez et al. 2011; Ferrucci 1991, 1998). No Brasil são 30 espécies (17 endêmicas) que ocorrem em diversos tipos vegetacionais (BFG 2015).

Com relação à tribo Cupanieae, o conceito de Radlkofer (1934) foi mantido durante muito tempo até o trabalho de Müller \& Leenhouts (1976), que questionaram a validade de Cupanieae como distinta de outras duas tribos (Schleichereae e Nephelieae). Em seguida, Harrington et al. (2005) apresentaram um estudo filogenético com o uso de marcadores moleculares em que os integrantes da tribo sensu Radlkofer (1934) formaram um clado e posteriormente, Buerki et al. (2009) demonstraram que o grupo informal chamado de "Cupania group", assim como o relacionamento com os outros clados, apresentam apenas baixo suporte. Desta maneira, é claro que estudos mais aprofundados, como exemplo, análises filogenéticas com amostragem exaustiva de gêneros e espécies de Cupanieae e das tribos relacionadas são necessários, não só para esclarecer o relacionamento entre as tribos, como também entre seus integrantes.

Entre os gêneros de Cupanieae, Cupania L. é o que mais se assemelha com Matayba, compartilhando numerosos caracteres morfológicos e distribuição neotropical (Somner \& Ferrucci 2004). Porém, em Matayba, as sépalas são unidas formando um cálice cupular e 5-lobado (sépalas curtas), enquanto em Cupania, as sépalas são compridas e livres. Essas diferenças são manifestadas nos botões florais em consequência de Matayba apresentar a abertura precoce do cálice, enquanto em Cupania, o cálice se abre simultaneamente com a corola.

Radlkofer (1934) separou as espécies de Matayba em quatro seções (M. sect. Ratonia (DC.) Radlk.; M. sect. Macaca Radlk.; M. sect. Apiomatayba Radlk. e M. sect. Matayba), separadas por características dos frutos e diferenças quanto à distribuição geográfica ao longo do continente americano.

Os representantes de $M$. sect. Ratonia, com quatro espécies, estão presentes apenas na América Central e Peru. Matayba sect. Macaca é formada por oito espécies concentradas na região amazônica e apenas um delas na América Central. Para o Brasil Radlkofer (1934) lista três espécies para esta seção: M. macrolepis Radlk., M. macrostylis Radlk. e $M$. arborescens Radlk.
Todas as 14 espécies de Matayba sect. Apiomatayba são distribuídas na Amazônia, exceto M. paucijuga Radlk. As 17 espécies de $M$. sect. Matayba ocorrem apenas na América do Sul, predominantemente no Brasil e fora da região Amazônica, com exceção de M. guianensis Aubl., com ampla distribuição e agora $M$. discolor (Spreng.) Radlk., devido à sinonimização de $M$. atropurpurea Radlk., também na Amazônia brasileira. Outras duas espécies que ocorrem em outros países da América do Sul são M. elaeagnoides Radlk., que além do sul e sudeste do Brasil, ocorre também no Paraguai, Uruguai e norte da Argentina e M. boliviana na Bolívia.

Após a monografia de Radlkofer (1934), foram descritas para $M$. sect. Matayba três novas espécies. Matayba cristae Reitz é uma espécie que ocorre nos estados do Paraná, Santa Catarina e São Paulo, enquanto M. obovata R.L.G. Coelho, V.C. Souza \& Ferrucci se apresenta distribuída nas florestas ombrófilas densas do Rio de Janeiro, São Paulo e Paraná; finalmente M. livescens (Radlk.) R.L.G. Coelho, V.C. Souza \& Ferrucci, ocorre principalmente nas florestas de restinga das regiões nordeste e sudeste do Brasil (Coelho et al. 2012, 2014).

A classificação das espécies em seções é mantida até o momento devido à falta de estudos mais completos. Já que esses grupos são formados principalmente por características dos frutos e distribuição geográfica, algumas exceções são conhecidas, como é o caso da espécie Matayba laevigata Radlk., que apesar de pertencente a seção Apiomatayba, é semelhante à M. guianensis Aubl. da seção Matayba (Acevedo-Rodríguez 2012). Por isso, são necessários maiores esforços para a atualização do conhecimento das seções do gênero, que possivelmente podem ser alteradas.

Por enquanto, o tratamento que abrange o maior número de espécies para o gênero Matayba tem sido o de Radlkofer (1934) em sua monografia para Sapindaceae. O presente trabalho conta com chaves de identificação, nomenclatura, descrições, ilustrações e mapas de distribuição das espécies, bem como observações sobre similaridade fenotípica, nomes populares e habitats de cada espécie.

\section{Material e Métodos}

O presente estudo foi realizado e baseado em revisão bibliográfica, em trabalhos realizados no campo e na análise dos materiais depositados nos seguintes herbários (Thiers et al., continuamente atualizado): B, BHCB, BM, BR, C, CTES, CVRD, EAC, ESA, F, FLOR, FUEL, G, GOET, HB, HRCB, HUEFS, IAC, IBGE, ICN, IPA, INPA, K, M, MBM, 
MBML, MO, MPU, NY, OUPR, P, PACA, PEL, R, RB, S, SP, SPF, SPSF, UB, UEC, US, VIC e W.

O presente trabalho descreve aspectos da arquitetura foliar, como a forma das nervuras secundária [retilíneas, arqueadas e curvadas (Fig. 1a,e,f)], o ângulo das nervuras secundárias em relação à nervura central [perpendiculares ou oblíquas (Fig. 1a,b)], a proeminência da nervação na face adaxial dos folíolos [proeminente ou inconspícua (Fig. 1c,d)] e a reticulação [fechada ou aberta (Fig.1e,f)]. Foram utilizados através do valor dos ângulos encontrados entre a nervura central e as secundárias os termos perpendicular $\left(70^{\circ}-90^{\circ}\right)$ e oblíquo (até $70^{\circ}$ ) para as nervuras secundárias (Fig. 1a,b). Tomando-se novamente como ponto de referência a nervura central, são apresentadas três terminologias principais para a
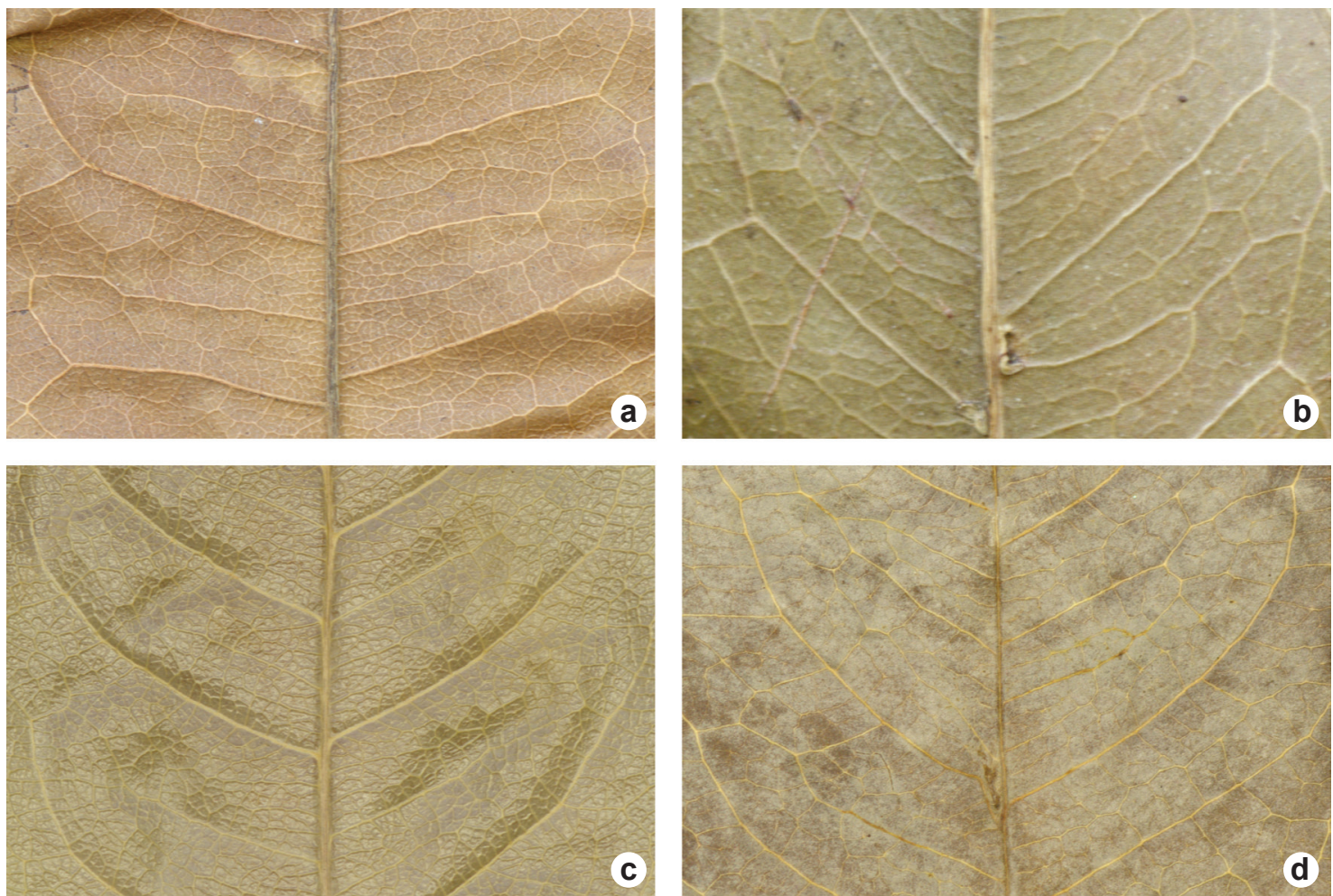

C
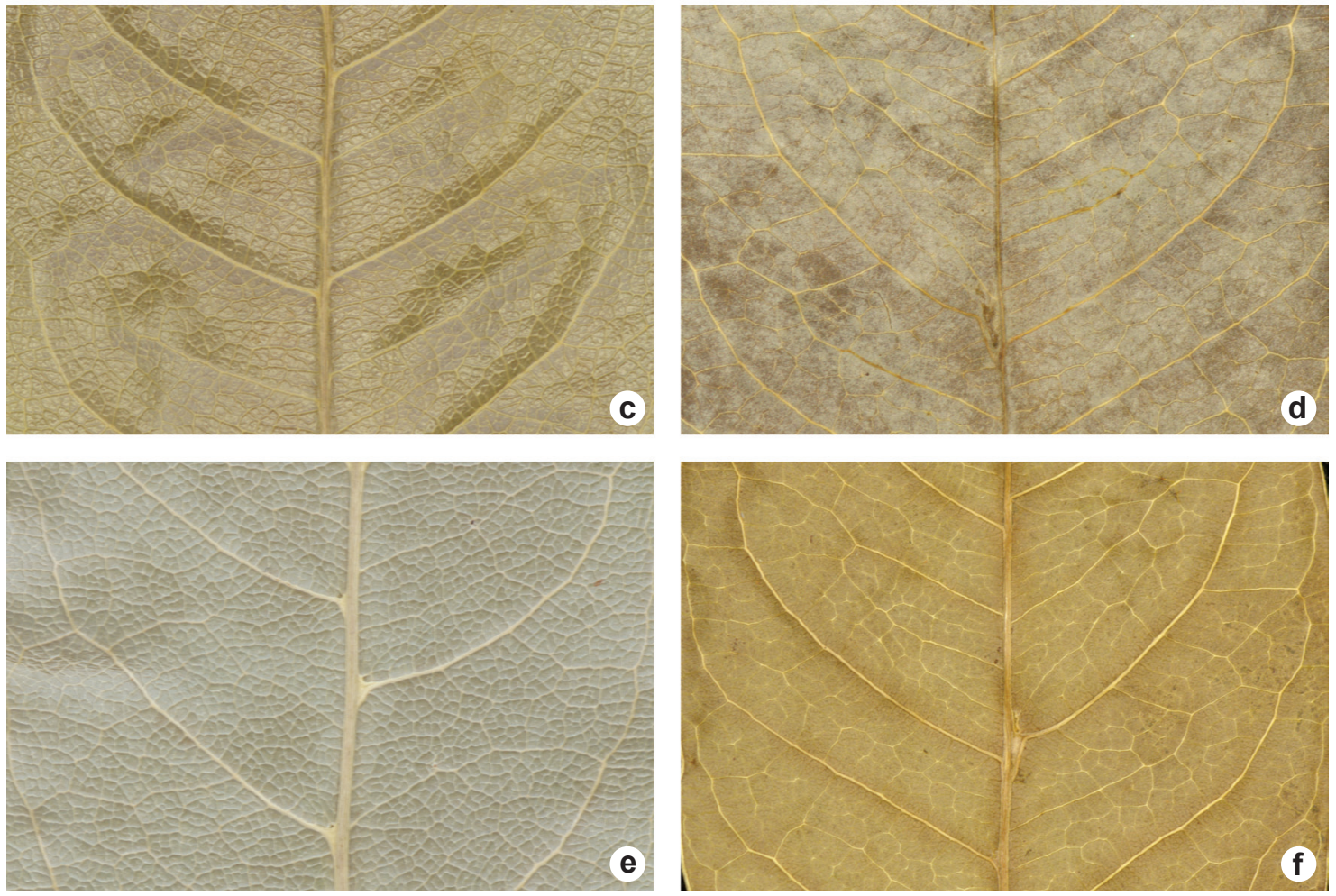

Figura 1 - Padrações da nervação - a. nervuras secundárias retilíneas; b. nervuras secundárias oblíquas; c. nervação proeminente na face adaxial dos folíolos; d. nervação inconspícua na face adaxial dos folíolos; e. nervação com reticulação fechada; f. nervação com reticulação da nervação aberta. [a. A.P. Duarte 5691 (RB, ESA); b. J.M. Silva 600 (MBM, ESA); c. L.C. Bernacci 25055 (UEC, ESA); d,f. J.N. Nakajima 57 (HUFU, ESA); e. S.R. Slusarski 299 (UEL, ESA)].

Figure 1 - Venation patterns - a. straight secundary veins; $b$. oblique secundar veins; c. prominent venation in the adaxial face of the leaflets; $d$. venation inconspicuous in the adaxial face of the leaflets; e. closed reticulated venation; f. open reticulated venation [a. A.P. Duarte 5691 (RB, ESA); b. J.M. Silva 600 (MBM, ESA); c. L.C. Bernacci 25055 (UEC, ESA); d,f. J.N. Nakajima 57 (HUFU, ESA); e. S.R. Slusarski 299 (UEL, ESA)]. 
descrição da forma das nervuras secundárias: retilínea (Fig. 2a), arqueada (Fig. 2b) e curvada (Fig. 2c). Estas designações foram determinadas dividindo o percurso da nervura secundária desde a nervura central até o início da formação do arco com a nervura secundária adjacente em três partes. Quando a nervura chega ao arco sem qualquer tipo de curvatura ou apenas na parte final, ela foi denominada retilínea. Quando se curva na segunda parte arqueada, e na terceira parte, curvada (Fig. 2). Sobre a proeminência da rede de nervuras na face adaxial dos folíolos, foi tomado como base o parâmetro utilizado pelos autores deste trabalho e que se encontra relacionado a trabalhos anteriores para o gênero Matayba (Radlkofer 1934) determinando como inconspícua ou proeminente a rede de nervuras na face adaxial dos folíolos (Fig. 1c,d).

Seguindo ainda a terminologia utilizada por Radlkofer (1934), a reticulação foi determinada como fechada ou aberta (Fig. 1e,f). Enquanto a fechada possui uma grande concentração de nervuras terciárias e quaternárias que confluem formando um sistema bastante reticulado (Fig. 1e), a reticulação aberta com um número menor de nervuras dessas ordens, apresenta grandes espaços entre elas e menor reticulação (Fig. 1f).

Além disso, a morfologia dos frutos tem um importante papel na caracterização das seções de Matayba assim como na distinção de algumas espécies.
O estípite do ovário após a frutificação desenvolve-se e, em algumas espécies, além do estípite, os lobos, que podem ser evidentes ou inconspícuos, apresentam evidências para a circunscrição dos táxons. Também são importantes, na separação das espécies, a superfície e indumento do epicarpo, coloração e indumento do endocarpo e o tamanho do arilo em relação à semente.

\section{Tratamento taxonômico}

Matayba Aubl. Hist. Pl. Guiane 1: 331, t. 128. 1775. Tipo: Matayba guianensis Aubl.

Árvores, arvoretas ou arbustos. Folhas compostas, alternas, paripinadas ou imparipinadas; folíolos geralmente inteiros, folíolo distal rudimentar, estípulas ausentes. Inflorescências em tirsos axilares ou terminais com as flores em dicásios. Flores pentâmeras, esbranquiçadas, bissexuais ou unissexuais funcionais, actinomorfas; sépalas (4-)5, curtas, unidas; pétalas de tamanho semelhante ou maior que as sépalas, presença de um apêndice petalífero basal; disco nectarífero anelar, lobado; estames (6-)8(-9); ovário (2-)3-carpelado com um único óvulo por carpelo, estigma 2- ou 3-lobado. Fruto 2- ou 3-locular, trígono ou lobado, coriáceo ou lenhoso, cápsulas loculicidas. Sementes globosas a elipsóides, ariladas. Embrião curvo, radícula curta e alojada em uma dobra do tegumento, cotilédones colaterais, crassos, plano-conexos.

\section{Chave de identificação para as seções do gênero Matayba Aubl.}

1. Cápsula alada ou subcocada, 2-3 lobadas

2. Folíolos geralmente com domácias; pétalas rudimentares Matayba sect. Ratonia

2'. Folíolos sem domácias; pétalas maiores que as sépalas com apêndice petalífero basal bipartido ..... Matayba sect. Macaca

1'. Cápsula estipitada

3. Cápsula 2-3-lobada, piriforme, subclavada ou obopiramidal; endocarpo glabro, glanduloso ou esparsamente piloso Matayba sect. Apiomatayba

3'. Cápsula curtamente estipitada, trígono-subglobosa ou elipsóide; endocarpo tomentoso 1. Matayba sect. Matayba

Matayba Aubl. sect. Matayba Radlk., Sitzungsber. Math.-Phys. Cl. Königl. Bayer. Akad. Wiss. München. 9: 630. 1879.

Tipo: Matayba guianensis Aubl.

\section{Caracterização morfológica}

de Matayba Aubl. sect. Matayba.

Espécies de Matayba sect. Matayba variam entre árvores e arbustos. A maioria das espécies apresenta algum tipo de indumento, mas sempre com tricomas simples. Nas partes vegetativas, os tricomas são geralmente curtos e podem variar em densidade, entre adpressos e curtos ou ainda longos e densamente distribuídos.

Nas inflorescências o indumento varia apenas em densidade. Nas flores se destaca o indumento de ambas as faces das sépalas e pétalas (também no apêndice petalífero basal). Considerando os estames, a porção dos filetes na qual estão inseridos os tricomas (basal, média ou alcançando o ápice) é importante 

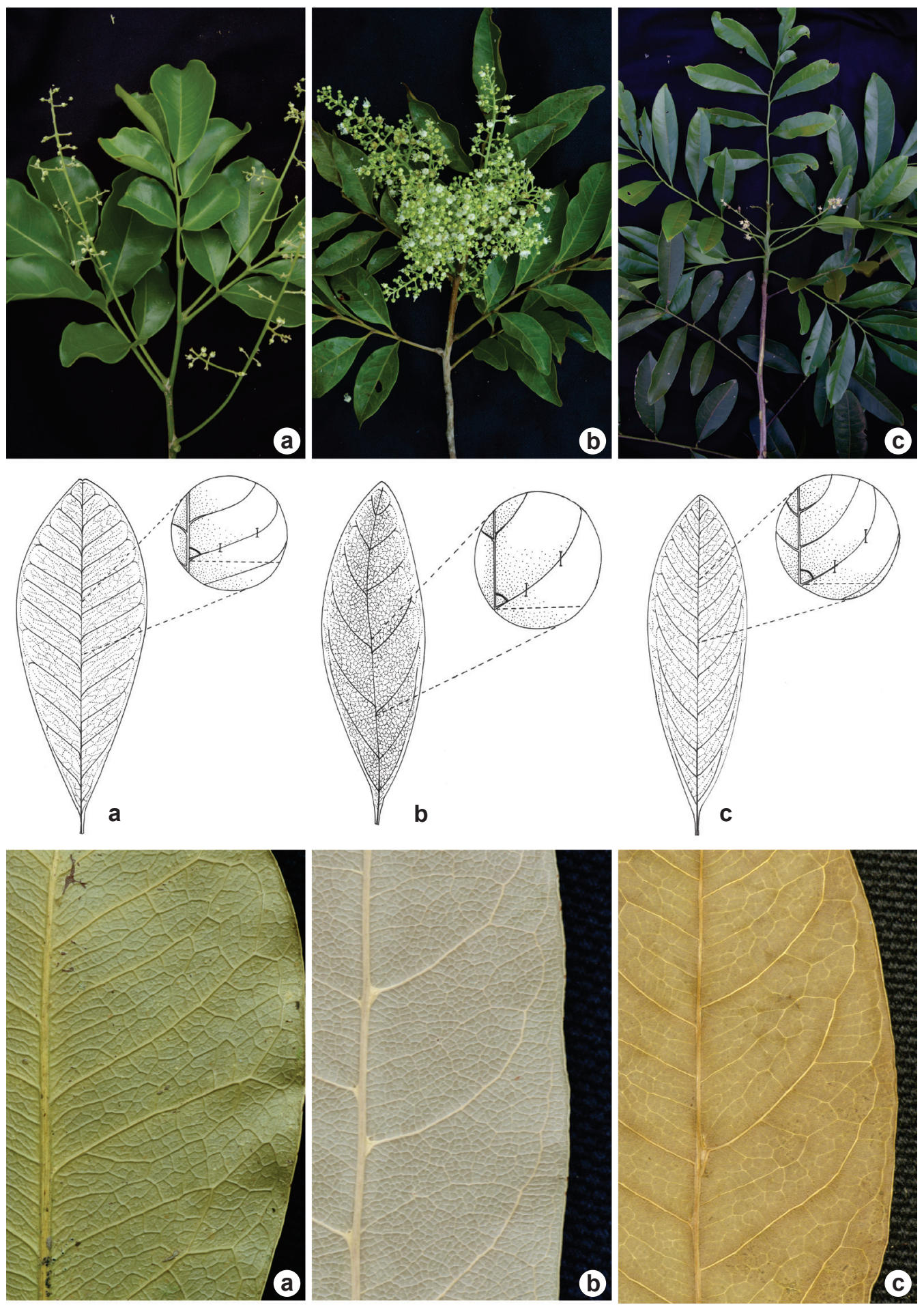

Figura 2 - Padrões dos folíolos e das nervuras secundárias - a. folíolos planos, nervuras secundárias retilíneas (curvada apenas no terço final); b. folíolos planos, nervuras secundárias arqueadas (curvadas no terço médio); c. folíolos conduplicados e recurvados, nervuras secundárias curvadas (curvadas no terço inicial) [a. P.R. Moraes 488 (ESA); b. S.R. Slusarski 299 (UEL, ESA); c. Nakajima 57 (HUFU, ESA)].

Figure 2 - Leaflets and secondary veins patterns - a. plain leaflets, rectilinear secondary veins (curved only in the final third); b. plain leaflets, arched secondary veins (curved in the middle third); c. leaflets concave and curved, bent secondary veins (curved in the first third) [a. P.R. Moraes 488 (ESA); b. S.R. Slusarski 299 (UEL, ESA); c. Nakajima 57 (HUFU, ESA)]. 
na diferenciação de algumas espécies. Nos frutos, o indumento do epicarpo varia em densidade, mas sempre apresentando tricomas curtos e adpressos, enquanto no endocarpo estes são longos e emaranhados.

As folhas são imparipinadas e geralmente são distribuídas por toda a extensão dos ramos ou são congestas na porção distal do caule e, além disso, apresentam um apículo na região distal da raque foliar, presente na maioria dos gêneros arbóreos de Sapindaceae. O pecíolo pode ser cilíndrico ou subcilíndrico, distalmente aplanado ou canaliculado e a raque varia entre cilíndrica e subcilíndrica, podendo ser achatada, canaliculada, bicanaliculada ou ainda subalada ou emarginada. Os folíolos são alternos ou subopostos, peciolulados, subsésseis ou sésseis, cartáceos a coriáceos, com margem inteira (exceção M. heterophylla) e podem ser conduplicados e/ou recurvados, ou ainda planos (Fig. 2).

Anervação secundária pode ser broquidódroma ou menos frequentemente eucamptódroma ( $M$. grandis Radlk.) ou craspedódroma ( $M$. heterophylla (Mart.) Radlk.). As nervuras secundárias são perpendiculares ou oblíquas, e ainda retilíneas, arqueadas ou curvadas (Figs. 1a,b; 2); a proeminência da nervação pode ser inconspícua na face adaxial dos folíolos ou proeminente (Fig. 1c,d) e a reticulação pode ser fechada ou aberta (Fig. 1e,f). As espécies que apresentam a nervação proeminente na face adaxial dos folíolos também apresentam a nervação fechada, com a exceção de Matayba stenodictya Radlk., que conta também com folíolos maduros com nervação inconspícua na face adaxial e visivelmente fechada na face abaxial.

As inflorescências na maioria das espécies são paniculiformes, geralmente axilares e raramente terminais em dicásios simples ou plurifloros e as brácteas e bractéolas acompanham o indumento da raque variando pouco na forma e no tamanho. As flores são díclinas, esbranquiçadas a amareladas. O cálice é cupular e 5-lobado e nas sépalas (curtas), o indumento das faces abaxial e adaxial, a partir de qual região elas se apresentam livres, o tamanho e a forma dos lobos são diagnósticos. Já o formato e o tamanho ds pétalas, e se elas são unguiculadas ou não, e, finalmente, o tamanho e indumento do apêndice petalífero devem ser analisados. As flores masculinas apresentam um androceu bem desenvolvido e um brevíssimo pistilódio que varia de 1-2 $\mathrm{mm}$ compr. com indumento denso ou em certas regiões glabro; estames 8(-9), 2-5 mm compr., com filetes sinuosos ou retos, desiguais ou iguais em tamanho e com indumento variável. Nas flores femininas, apesar de visualmente bissexuais, os estames com filetes sempre pubescentes são menores que nas flores masculinas e com as anteras indeiscentes (e portanto considerados estaminódios); o gineceu (2-)3-carpelar varia de 3-6(-7) mm compr., o ovário é trígono, subgloboso a obovado, levemente lobado a evidentemente lobado; estilete 1-5 mm compr. com variação na densidade do indumento; estigma com lobos unidos (capitados) ou livres (bífidos ou trífidos).

Finalmente, as cápsulas são estipitadas ou sésseis, lobuladas ou não, apresentam epicarpo com superfície subverrucosa a tuberculada, glabra, pubérula a densamente pubescente; endocarpo com indumento de tricomas longos, variando na densidade e coloração, e sementes oblongas, elipsoides ou obovóides com arilo esbranquiçado a recobrindo em diferentes partes.

\section{Chave de identificação para as espécies de Matayba sect. Matayba}

1. Folíolos com nervação proeminente na face adaxial.

2. Nervação broquidódroma.

3. Folíolos discolores; conduplicados e recurvados

3'. Folíolos concolores; planos.

4. Domácias urceoladas sempre presentes, nervuras secundárias arqueadas.

5. Raque das folhas glabra a subglabra; face adaxial dos folíolos com nervação amarelada a avermelhada; nervura central impressa; sépalas na face abaxial (sub) glabras . 4. Matayba elaeagnoides

5'. Raque das folhas pubérula a esparsamente pubescente; face adaxial dos folíolos com nervação esbranquiçada a amarelada; nervura central proeminente; sépalas na face abaxial pubescentes a tomentosas. 9. Matayba leucodictya

4'. Domácias urceoladas ausentes ou raramente presentes, nervuras secundárias retilíneas. 
6. Folíolos esverdeados, cartáceos; sépalas livres a partir da região basal, lobos de $0,5-1,5 \mathrm{~mm}$ compr.; epicarpo pubérulo........................................................ 10. Matayba juglandifolia

6'. Folíolos amarelados a alaranjados, coriáceos; sépalas livres a partir da região mediana, lobos 0,7-1 mm compr.; epicarpo glabro a subglabro................................... 14. Matayba obovata

2'. Nervação eucamptódroma ou craspedódroma

7. Margem dos folíolos inteira 5. Matayba grandis

7'. Margem dos folíolos serrulada ou serreada 7. Matayba heterophylla

1'. Folíolos com nervação inconspícua na face adaxial.

8. Raque das folhas subalada ou marginada.

9. Margem dos folíolos serrulada ou serreada. Cápsula com estípite de 4-8 mm compr., 1-seminada 7. Matayba heterophylla

9'. Margem dos folíolos inteira. Cápsula com estípite de 1-2 mm compr., 2-3 seminadas

12. Matayba marginata

8'. Raque das folhas cilíndrica ou subcilíndrica.

10. Folíolos pubescentes na face abaxial.

11. Folíolos elípticos, elíptico-lanceolados, ovados ou oblongos; geralmente conduplicados, nervuras secundárias de 8-12 pares. Flores de 6-9 mm compr. e pétalas de 1-2,5 mm compr. 13. Matayba mollis

11'. Folíolos largamente obovados ou largamente elípticos; planos, nervuras secundárias de 3-6 pares. Flores ca. $4 \mathrm{~mm}$ compr. e pétalas menores que $1 \mathrm{~mm}$ compr.

15. Matayba punctata

10'. Folíolos glabros a subglabros na face abaxial.

12. Folíolos discolores; domácias ausentes.

13. Folíolos conduplicados e recurvados.

14. Reticulação da nervação aberta

15. Nervuras secundárias perpendiculares; sépalas na face adaxial glabras; filetes sinuosos. 3. Matayba discolor

15'. Nervuras secundárias oblíquas; sépalas na face adaxial pubescentes; filetes retos ...... 11. Matayba livescens

14'. Reticulação da nervação fechada 16. Matayba stenodictya

13'. Folíolos planos.

16. Pedicelo $2-3 \mathrm{~mm}$ compr.; estilete $1-1,5 \mathrm{~mm}$ compr., estigma trífido, esparsamente a densamente pubescente (RJ, SP, PR, SC, RS)

8. Matayba intermedia

16'. Pedicelo 1-2 mm compr.; estilete inconspícuo; estigma capitado, tomentoso (Bolívia) 1. Matayba boliviana

12'. Folíolos concolores; domácias geralmente presentes.

17. Nervuras secundárias retilíneas ou levemente arqueadas; folíolos planos.

18. Folíolos sésseis; domácias urceoladas, numerosas, salientes na face adaxial dos folíolos 2. Matayba cristae

18'. Folíolos peciolulados; domácias foveoladas, poucas, não salientes na face adaxial dos folíolos. 17. Matayba sylvatica

17'. Nervuras secundárias curvadas; folíolos geralmente conduplicados e recurvados. 6. Matayba guianensis

\section{Matayba sect. Matayba}

1.1. Matayba boliviana Radlk., Bull. Torrey Bot. Club. 25(6): 336. 1898. Tipo: BOLÍVIA. LA PAZ. Coripata. IV.1884. M. Bang 2171 (lectótipo $\mathrm{M}$ ! [aqui designado]; isolectótipos $\mathrm{BM}, \mathrm{C}$ !, $\mathrm{CM}$, CORD, F!, G!, GH, K!, M!, MICH, MIN, MO, NY!, PH, US!, W!).
Arbustos ou árvores, 2-4,5 m alt.; ramos cilíndricos a achatados, glabros a esparsamente pubescentes. Folhas dispersas por todo o ramo, pecíolo 0,5-3,4 cm compr., subcilíndrico, (esparsamente) pubescente; raque 1,1-6,2 cm compr., subcilíndrica, canaliculada a bicanaliculada, subglabra a pubescente, com tricomas adpressos; 
folíolos 2-6, subsésseis; lâmina 2,1-8,6 × 1-3,7 $\mathrm{cm}$, geralmente obovados, raramente elípticos a elíptico-obovados, cartáceos, planos, ápice obtuso a arredondado, raramente retuso, base atenuada, assimétrica, margem subrevoluta a revoluta, inteira; concolores, castanhos, (sub)glabros na face abaxial, castanho-acinzentado, castanho-claro ou castanhoesverdeado, brilhantes e (sub)glabros na face adaxial; nervação castanho a castanho-esverdeada, inconspícua na face adaxial, reticulação aberta; nervura central plana na face adaxial, glabra a esparsamente pubescente em ambas as faces; nervação secundária broquidódroma, 4-12 pares, oblíquas, nervuras secundárias proeminentes na face adaxial, retilíneas; domácias ausentes. Inflorescências axilares, mais curtas que as folhas; pedúnculo 2,5-6,8 $\mathrm{mm}$ compr., subcilíndrico a achatado, pubescente (densamente); raque 1-12,4 mm compr., achatada, pubescente (densamente). Flores 5-6 mm compr.; pedicelo 1-2 mm compr., articulado próximo à região basal ou central, densamente pubescente; sépalas $1-1,5 \mathrm{~mm}$ compr., ovaladas, livres a partir da região mediana, lobos $0,5-0,7 \mathrm{~mm}$ compr., ápice arredondado; pubescentes (densamente) na face abaxial e pubescentes na face adaxial, margem ciliada; pétalas ca. $1 \mathrm{~mm}$ compr., obovadas, ápice truncado, erodido, glabras na face abaxial e vilosas na face adaxial; base unguiculada; apêndice petalífero basal de mesmo tamanho ou menor que a pétala, viloso; disco nectarífero glabro; fl. masc.: estames 2,5-3 mm compr., filetes iguais, retos a levemente sinuosos, pubescentes na região basal, anteras glabras; pistilódio ca.1,5 mm compr., tomentoso; fl. fem.: estaminódios ca. $2 \mathrm{~mm}$ compr.; gineceu ca. $2 \mathrm{~mm}$ compr., ovário obovóide a ovóide, tricarpelar, estilete inconspícuo, estigma capitado, tomentoso. Cápsulas e sementes desconhecidas Material examinado: BOLÍVIA. LA PAZ: Puente Villa, $4 \mathrm{~km}$ hacia Coripata, 8.XII.1994, fl., S.T. Beck 21643, 21645 (CTES, LPB).

Matayba boliviana é endêmica à Bolívia em fragmentos de florestas montanhosas a cerca de $1750 \mathrm{~m}$ alt. Esta é a única espécie da seção Matayba que ocorre exclusivamente fora do território brasileiro e ainda na face oriental da Cordilheira dos Andes.

Semelhante morfologicamente a $M$. intermedia devido à forma, consistência e nervação dos folíolos (inconspícua na face adaxial, reticulação aberta e nervuras secundárias retilíneas), além da ausência de domácias. Contudo diferem, além da distribuição geográfica, pelo pedicelo (1-2 mm compr. em M. boliviana e 2-3 mm compr. em $M$. intermedia) e o estigma (capitado em M. boliviana, trífido em M. intermedia).

1.2. Matayba cristae Reitz., Fl. Il. Catarin. 1: 139. 1980. Tipo: BRASIL. SANTA CATARINA. Guaruvá. Monte Crista. 2.IX.1960. R. Reitz \& R. R. Klein 9800 (holótipo HBR!; isótipo M!).

Árvores ou arvoretas, 3-11 m alt.; ramos cilíndricos, glabros a esparsamente pubescentes. Folhas dispersas por todo o ramo, pecíolo 1,8-3,2 cm compr., subcilíndrico, glabros a pubescentes; raque 1,4-9 cm compr., subcilíndrica a bicanaliculada, glabra a esparsamente pubescente; folíolos 2-6, sésseis; lâmina 2,8-8,2 × 0,9-2,5 cm, geralmente elípticos, raramente oblongos a oblanceolados, cartáceos a subcoriáceos, planos, ápice agudo a cuspidado, base atenuada, assimétrica, margem revoluta, inteira; concolores, verde-escuros, (sub) glabros na face abaxial, verde-acinzentados, verdeclaros a verde-escuros, (sub)glabros na face adaxial; nervação esbranquiçada a acinzentada, inconspícua na face adaxial, reticulação aberta; nervura central levemente proeminente na face adaxial, pubescente; nervação secundária broquidódroma, 4-8 pares, levemente proeminentes na face adaxial, oblíquas, retilíneas a arqueadas; domácias urceoladas presentes, salientes na face adaxial dos folíolos. Inflorescências axilares, mais curtas que as folhas; pedúnculo $0,2-2,9 \mathrm{~cm}$ compr., subcilíndrico a achatado, pubérulo a pubescente, raque 1,6-8,8 cm compr., achatada, subglabras a esparsamente pubescentes. Flores 5-9 mm compr.; pedicelo 1-4 mm compr., articulado geralmente na região basal, raramente nas regiões central ou apical, pubescente; sépalas 1-2 mm compr., ovaladas (largamente), livres a partir da base, lobos 0,7-1,5 $\mathrm{mm}$ compr., ápice obtuso a agudo; pubescentes em ambas as faces; pétalas 1-2 mm compr., obovadas a oblongas, ápice obtuso a arredondado, erodido, glabras na face abaxial, vilosas na face adaxial, margem ciliada; base unguiculada ou séssil; apêndice petalífero basal geralmente do mesmo tamanho ou maior que a pétala, viloso; disco nectarífero glabro; fl. masc.: estames ca.3 $\mathrm{mm}$ compr., filetes iguais, retos, pubescentes na região basal e subglabros a pubescentes nas regiões central e apical, anteras glabras; pistilódio ca.1 $\mathrm{mm}$, tomentoso; fl. fem.: desconhecidas. Cápsulas $1-1,7 \times 0,9-1,6 \mathrm{~cm}$, subglobosas, elipsoides a obovóides, levemente lobadas, estípite ca. $2 \mathrm{~mm}$ compr., apiculadas, bicarpelares ou tricarpelares, 1-2 seminadas; epicarpo coriáceo, verrucoso, 
esparsamente pubescente; endocarpo viloso castanho-escuro. Sementes 0,8-1,2 × 0,7-1 cm, oblongas; arilo amarelado recobrindo até a região apical da semente.

Nomes populares: camboatá-mirim, camboatá, cubatã-do-crista.

Material selecionado: BRASIL. PARANÁ: Guaratuba, Rio Itararé, 17.VIII.1994, fl., J.M. Silva 1372 (MBM); Morretes, Ninho do Gavião, Serra Marumbi, 3.X.1948, fl., G. Hatschbach 1011 (MBM); Paranaguá, trilha para Torre da Prata, 1.VII.2003, fl., J.M. Silva 3753 (MBM); Piraquara, rio Taquari, 29.IX.1951, f1., G. Hatschbach 2519 (MBM); Quatro Barras, Morro Sete, 23.XI.1988, fr., J.M. Silva 600 (ESA, HUEFS, MBM, SPF, UB); São José dos Pinhais, Purgatório, 10.IX.1982, fl., G. Hatschbach 45288 (MBM). SANTA CATARINA: Garuva, Monte Cristo, 6.X.1960, fr., R. Reitz 10037 (FLOR, HBR); Joinville, Castelo dos Bugres, 25.XI.2004, fr., F.C.S. Silveira 637 (FURB). SÃO PAULO: Cajati, Estação Repetidora da Serra do Aleixo, torre da Embratel, 30.IX.2002, fl., J.M. Silva 3649 (CESJ, HUEFS, MBM).

Espécie encontrada nas regiões sul (PR, SC) e sudeste (SP) do Brasil em florestas de encosta, beira de rios, matas nebulares e na transição entre a floresta ombrófila densa e a floresta ombrófila mista, em altitudes variando entre 1000 e 1200 metros. Coletada com flores de agosto a outubro e com frutos nos meses de novembro e dezembro.

Matayba cristae pode ser confundinda com a espécie simpátrica $M$. elaeagnoides pela presença de domácias urceoladas, mas é facilmente diferenciada pelas mesmas estruturas que são salientes na face adaxial dos folíolos (não em $M$. eleagnoides), pela rede de nervuras aberta e inconspícua na face adaxial ( $v s$. fechada e proeminente) e as nervuras secundárias que são geralmente retilíneas ou raramente arqueadas ( $v s$. sempre arqueadas), e o o apêndice petalífero basal geralmente menor que a pétala ( $v s$. mesmo tamanho).

1.3. Matayba discolor (Spreng.) Radlk., Sitzungsber. Math.-Phys. Cl. Königl. Bayer. Akad. Wiss. München 9: 630. 1879; Terminalia discolor Spreng., Neue Entdeck. Pflanzenk. 2: 111. 1821. Tipo: BRASIL. BAHIA. s/d, F. Sellow 110 (lectótipo B! [aqui designado]; isolectótipos F!, M!).

Terminalia octandra Spreng. ex Eichler, in Mart., Fl. bras. 14(2): 93. 1867. nom. nud.

Matayba atropurpurea (Radlk.) Radlk., in Mart., F1. bras. 13(3): 617. 1900; Matayba discolor f. atropurpurea Radlk., Sitzungsber. Math.-Phys. Cl. Königl. Bayer. Akad. Wiss. München 9: 631. 1879. Tipo: BRASIL. AMAZONAS. Alto Amazonas, prope Panuré ad flumen Uaupés. XII.1852. $R$.
Spruce 2790 (lectótipo K! [aqui designado]; isolectótipos $\mathrm{P}$ !, W!).

Árvores ou arbustos, 1,7-10 m alt.; ramos cilíndricos, glabros. Folhas distribuídas por todo o ramo; pecíolo 1,2-4,4 cm compr., cilíndrico ou subcilíndrico, subglabro; raque 1,2-9,7 cm compr., subcilíndrica, canaliculada a bicanaliculada, subglabra a esparsamente pubescente; folíolos 4-6, peciólulos 0,3-1 cm compr., canaliculados, subglabros a esparsamente pubescentes; lâmina $(1,8-) 3-15,1 \times 1,4-6,8 \mathrm{~cm}$, largamente elípticos, elíptico-obovados, largamente obovados ou elíptico-ovalados, cartáceos a coriáceos conduplicados, recurvados, ápice agudo, obtuso, arredondado ou retuso, base aguda a atenuada, assimétrica ou simétrica; margem subrevoluta a revoluta, inteira; discolores, castanho-claros, castanho-escuros a vinho, glabros a subglabros na face abaxial, verde-escuros, verde-acinzentados, castanho-avermelhados a enegrecidos, as vezes brilhantes, glabros a subglabros na face adaxial; nervação verde-acinzentada, verdeamarelada, castanho-avermelhada, inconspícua na face adaxial, reticulação aberta; nervura central levemente proeminente a plana na face adaxial, (sub)glabra em ambas as faces; nervação secundária broquidódroma, 8-18 pares, levemente proeminentes na face adaxial, perpendiculares, retilíneas a raramente arqueadas; domácias ausentes. Inflorescências axilares, mais ou mais curtas que as folhas; pedúnculo $0,7-14,5 \mathrm{~cm}$ compr., cilíndrico a achatado, esparsamente pubescente, raque 3,4-13,4 cm compr., achatada, (esparsamente) pubescente. Flores 5-7 mm compr.; pedicelo 1-2 mm compr., articulado nas regiões basal, central e apical, pubescente; sépalas 1-1,5 mm compr., ovaladas (largamente), livres a partir da região mediana, lobos $0,5-0,7 \mathrm{~mm}$ compr., ápice agudo, obtuso ou arredondado; (esparsamente) pubescentes (densamente) na face abaxial, glabras na face adaxial, margem ciliada; pétalas ca.1 mm compr., obdeltoides, ápice emarginado a truncado, erodido, glabras a subglabras na face abaxial, lanosas na face adaxial, margem ciliada; base unguiculada; apêndice petalífero basal menor, maior ou de mesmo tamanho que a pétala, lanoso; disco nectarífero (sub)glabro; fl. masc.: estames ca.2-4 mm compr., filetes geralmente iguais, raramente desiguais, sinuosos, pubescentes da região central a apical,, anteras subglabras, pistilódio ca. $1 \mathrm{~mm}$, densamente pubescente; fl. fem.: estaminódios ca.1,5 mm compr.; gineceu 3-4 mm compr., ovário ovóide, lobado, densamente 
pubescente; estilete 1-2 mm compr., estigma bífido ou trífido, esparsamente pubescentes. Cápsulas 1,3-2 × 0,9-1,9 cm, globosas ou subglobosas, levemente lobadas, estípite 1-2 mm compr., apiculadas ou não; bicarpelares a tricarpelares, (1-) 2-3 seminadas, epicarpo subcoriáceo a coriáceo, subverrucoso a verrucoso, raramente tuberculado, subglabro a pubérulo; endocarpo densamente tomentoso, amarelado. Sementes $0,9-1,4 \times 0,5-0,9 \mathrm{~cm}$ compr., oblongas a obovóides; arilo alvo a amarelado recobrindo até a região apical da semente.

Nomes populares: camboatá-branco, camboatá-de-cotia, pitomba-rosa e zeca-tatú.

Material selecionado: BRASIL. ALAGOAS: Maceió, restinga da praia do Francês, 26.I.1983, fl., J.R. Pirani 2673 (CTES, NY, RB, SP, SPF). AMAPÁ: Campo Verde, estrada da Zona Perimetral, 25.X.1979, bt., fl., D.F. Austin 7226 (NY). AMAZONAS: Alto Amazonas, prope Panuri ad Rio Maupés. X.1852-I.1853, fl., F. Sellow 2790 (B, K, M, W). BAHIA: fl., F. Sellow 1008 (K); 1834, fl., J.S. Blanchet 1664 (G); 1854, fl., J.S. Blanchet 1691 (G); Belmonte, along to road to Itapebi, 25.III.1974, fl., R.M. Harley 17403 (K, RB); Comandatuba, ca. 5 km na estrada Comandatuba, 4.XII.1991, bt., fl., A. Amorim 526 (CEPEC, HUEFS, MBM); Ilhéus, Sambaitaba, 17.I.1993, fr., W. Thomas 9550 (CEPEC, MBM, NY); Maraú, ca. $3 \mathrm{~km}$. de Maraú, na rodovia para Saquaíra, 2.II.2000, fl., J.G. Jardim 2649 (CEPEC, CTES, MBM); Salvador, Dunas de Abaeté, 8.X.1986, fl., M.L. Guedes 1163 (ALCB, RB); Una, Comandatuba, ca. 10 km. SE de Una, 3.X.1981, fl., A.M. de Carvalho 892 (CEPEC, CTES). ESPÍRITO SANTO: Conceição da Barra, Itaúnas, 20.V.1999, bt., fl., G. Hatschbach 69181 (MBM); Linhares, Reserva Natural da CVRD, 1.I.1998, fl., M. Simonelli 887 (CVRD, ESA). PARÁ: Belém, Boa Vista, Rio Guamá, 1.XI.1980, fr., D.C. Daly et al. 790 (INPA, MG, NY); Jacareacanga, Reserva Crapuri, VIII.2012, fr., F.C.A. Lucas 928 (MFS). PARAÍBA: João Pessoa, Mangabeira, 13.XI.1992, fl., O.T. Moura 907 (JPB). PERNAMBUCO: Recife, Mata de Dois Irmãos, fl., C.G. Leal 32 (RB); Rio Formoso, Cupe, Praia do Muro Alto, 6.II.1970, fl., A.D. Andrade-Lima 70-5732 (INPA). SERGIPE: Aracajú, Horto do IBDF (Ibura), fl., 9.I.1988, E.L.M. Catharino 1293 (SP, SPF).

Matayba discolor é encontrada nas regiões norte (AM, AP, PA), nordeste (AL, BA, PE, PB e $\mathrm{SE}$ ) e sudeste (ES) do Brasil, principalmente em florestas de restinga e em florestas de tabuleiro. $\mathrm{Na}$ floresta amazônica é encontrada em solo arenoso próximo aos rios. Foi coletada com flores de novembro a junho e com frutos de novembro a abril.

Esta espécie assemelha-se a $M$. intermedia por apresentar a nervação inconspícua na face adaxial dos folíolos, as nervuras secundárias geralmente retilíneas e os folíolos discolores sem domácias. Os folíolos conduplicados e recurvados em $M$. discolor e as nervuras secundárias praticamente perpendiculares com relação à nervura central diferem dos folíolos planos com as nervuras secundárias oblíquas de $M$. intermedia. $\mathrm{O}$ aspecto final que distingue as espécies é a distribuição geográfica. Matayba discolor é distribuída no Amazonas e do Pernambuco ao Espírito Santo, enquanto M. intermedia ocorre do Rio de Janeiro ao Rio Grande do Sul, também em florestas de restinga, porém com maior frequência nas florestas de encosta.

Radlkofer (1879) reconheceu duas formas para Matayba discolor, M. discolor f. discolor e $M$. discolor f. atropurpurea, diferenciadas apenas pela coloração dos folíolos na face adaxial e indumento das inflorescências. Em 1900, este mesmo autor elevou a segunda forma como uma espécie: Matayba atropurpurea (Radlk.) Radlk. Após observado o material tipo de $M$. atropurpurea e uma quantidade significativa de materiais referentes a $M$. discolor, as características descritas por Radlkofer (1900, 1934) para a separação desses táxons são contínuas e desta maneira, esse nome é agora reconhecido como um sinônimo de $M$. discolor.

1.4. Matayba elaeagnoides Radlk., Sitzungsber. Math.-Phys. Cl. Königl. Bayer. Akad. Wiss. München. 9: 635. 1879. Tipo: BRASIL. MINAS GERAIS. 1.I.1845. J.F. Widgren 1083 (lectótipo: $\mathrm{S}$ ! [aqui designado]; isolectótipos: $\mathrm{B}$ !, BR! C!, GOET!, K!, M!).

Matayba pallens Radlk. in Martius, Fl. bras. 13(3): 628. 1900. Tipo: BRASIL. SÃO PAULO. s/d, A. Loefgren 996 (lectótipo C! [aqui designado]; isolectótipo SP!)

Árvores ou arbustos, 3-15 m alt.; ramos cilíndricos a levemente achatados, glabros a esparsamente pubescentes. Folhas dispersas por todo o ramo, raramente congestas no ápice; pecíolo 1,2-5,4 $\mathrm{cm}$ compr., cilíndrico a bicanaliculado, (sub)glabro; raque 1,2-9,7 cm compr., subcilíndrica, bicanaliculada, (sub) glabra; folíolos 4-12, subsésseis ou peciólulos 0,3-0,4 cm compr., canaliculados, subglabros a esparsamente pubescentes; lâmina 1,2-12,9 $\times 0,6-3,7 \mathrm{~cm}$, obovados, obovado-oblongos, elípticos, elíptico-obovados, estreitamente elípticos a oblanceolados, cartáceos, planos, ápice agudo, obtuso, arredondado ou retuso, base atenuada, 
assimétrica ou simétrica, margem revoluta, inteira; concolores, verde-amarelado a castanho-claro na face abaxial, (sub)glabros na face abaxial, verdeescuro, verde-acinzentado, verde-esbranquiçado, acinzentado a castanho-acinzentado, as vezes brilhantes, glabros na face adaxial; nervação amarelada a avermelhada, proeminente na face adaxial, reticulação fechada; nervura central impressa na face adaxial, (sub)glabra em ambas as faces; nervação secundária broquidódroma, 4-12 pares, impressas a planas na face adaxial, oblíquas, geralmente arqueadas a levemente arqueadas; domácias presentes, urceoladas com tricomas na abertura, não salientes na face adaxial dos folíolos. Inflorescências axilares, paniculiformes, menos compridas que as folhas; pedúnculo $0,5-7,5 \mathrm{~cm}$ compr., cilíndrico a achatado, glabro a pubescente, raque 0,3-11,5 cm compr., achatada, subglabra a pubescente. Flores 4-8 mm compr.; pedicelo 1-2 mm compr., articulado da base ao ápice, pubescente; sépalas ca.1,5 mm compr., ovaladas, livres a partir das regiões basal ou mediana, lobos $1 \mathrm{~mm}$ compr., ápice obtuso a arredondado; (sub)glabras na face abaxial, pubescentes na face adaxial, margem ciliada; pétalas ca.1,5 mm compr., ovaladas, ápice emarginado, truncado ou arredondado, erodido ou irregular, (sub)glabras na face abaxial, vilosa na face adaxial, margem ciliada; base unguiculada, apêndice petalífero basal menor ou de mesmo tamanho que a pétala, lanoso a densamente lanoso; disco nectarífero glabro; fl. masc.: estames 2-4 mm compr., filetes geralmente iguais, raramente desiguais, geralmente retos, raramente sinuosos, pubescentes (esparsamente pubescentes na região apical), anteras (sub)glabras; pistilódio ca. $1 \mathrm{~mm}$ compr., densamente pubescente; fl. fem.: estaminódios ca.1,5 mm compr.; gineceu 2,5-4 mm compr., ovário ovóide a globoso, levemente lobado, densamente pubescente; estilete ca. $1 \mathrm{~mm}$ compr., estigma capitado, esparsamente pubescente. Cápsulas 0,6-1,9 × 0,4-1,9 cm, globosas, levemente lobadas, estípite 1-3 mm compr., apiculadas; tricarpelares, 1-3 seminadas, epicarpo coriáceo, verrucoso a fortemente verrucoso, pubérulos a densamente pubescentes; endocarpo tomentoso, ferrugíneo. Sementes 0,7-1 $\times 0,5-0,8 \mathrm{~cm}$, oblongas a obovóides; arilo alvo a amarelado recobrindo totalmente ou até a região apical da semente.

Nomes populares: arolera-branca, camboatá, camboatá-branco, cuvantã, craguatã, cragoatãbranco, cangroata-branco, cangroatan, mataiba, miguel-pintado, pau-de-pombo.
Material selecionado: ARGENTINA. CORRIENTES: Ituzaingó, Isla Apipé Grande, Panco cué, 4.X.1978, fl., A. Schinini 15704 (CTES, ICN). MISIONES: Candelaria, Santa Ana, borda ruta nacional 12, 12.XII.1992, fr., $M$. Rodríguez 380 (CTES). BRASIL. MATO GROSSO DO SUL: Eldorado, Rodovia BR-642, 21.X.1988, fr., G. Hatschbach 51502 (MBM). MINAS GERAIS: Caldas, 1863-1864., fl., A.F. Regnell II38 (BR, C, K, S); fl., J.F. Widgren 1123 (BR, S); fl., J.F. Widgren 1184 (BR, S); fl., H. Lindberg 423 (S); fl., C.W.H. Mosén 832 (S); fl., C.W.H. Mosén 4038 (S); fl., C.W.H. Mosén 4039 (S); Casa Branca, 22.VII.1894, fl., A.A.M. Gomes 1340 (M); São Bartholomeu, 22.VIII.1884, fr., A.F.M. Glaziou $14576^{a}(\mathrm{P})$; São Thomé das Letras, estrada de São Thomé das Letras, Morro do Gavião, 2.XI.1984, fl., L. Rossi CFCR 5750 (SPF). PARANÁ: Bocaiúva do Sul, Colônia João XXII, 26.XI.1986, fl., G. Hatschbach 50813 (ICN, HUCS. MBM); Capão Grande, XI.1909, fl., P.K.H. Dusén 7696 (sintipo M!); Ponta Grossa, X.1900, fl., P.K.H. Dusén 1037 (M); Serrinha, XII.1908, fl., P.K.H. Dusén 7363 (M). RIO GRANDE DO SUL: fl., F. Sellow 1513 (B, M); fl., F. Sellow 2053 (M); fl. e fr., F. Sellow 3141 (B); Campränder, Estância Jeremias, 20.X.1905, fl., J.F.N. Bornmüller 607 (M); Farroupilha, Estação experimental Fruticultura, 20.XI.1950, fl., $B$. Rambo 431 (HAS); Jundiaí do Sul, fazenda Monte Verde, 23.XI.2000, fr., J. Carneiro 824 (CESJ, MBM, UB). SANTA CATARINA: Lajes, Encruzilhada, 5.XII.1962, fl., R.M. Klein 3188 (FLOR); Piraí, 27.XII.1903, fr., $P$. Dusén 2980 (R). SÃO PAULO: fl., W.J. Burchell 3977 (BR); XI.1933, fl., C. Lund 1011 (BR, C, M); C.F.P. Martius (M); F. Sellow 193 (B); F. Sellow 271 (B); Sellow 1903-1392 (B); F. Sellow 5040 (B); Piracicaba, sítio Boa Vista, 13.XII.1994, fr., K.D. Barreto 3407 (BHCB, CTES, ESA, FUEL, HFC, HUM); São Paulo, Butantan, 7.IX.1917, fl., F.C. Hoenhe 519 (M, SP); Loreto, XI.1917, fl., F.C. Hoehne 1289 (M). PARAGUAI. ALTO PARANÁ: 1909-1910. K. Fiebrig 5969 (M); Plaine de Capitindu, à l'Este de la Cordillera de Ville-Rica, 30.IX.1875, fl., Balansa 2474 (G); Plaine de Capitindu, à l'Este de la Cordillera de Ville-Rica, 30.IX.1875, fl., Balansa $2475(\mathrm{G})$;

Matayba elaeagnoides é distribuída no Brasil nas regiões centro-oeste (MS), sudeste ( $\mathrm{MG}$, $\mathrm{SP})$ e sul (PR, SC e RS), no norte da Argentina (Corrientes e Missiones), no Paraguai oriental e no Uruguai. É encontrada principalmente no interior de florestas estacionais semidecíduas, em florestas ombrófilas mistas e menos frequentemente em florestas ombrófilas densas. Na Argentina e no Paraguai, $M$. elaeagnoides ocorre principalmente em florestas alagadas. Foi coletada com flores no período de maio a dezembro e com frutos entre setembro a janeiro e em abril.

Essa espécie pode ser reconhecida vegetativamente pela raque foliar bicanaliculada, 
nervuras secundárias geralmente arqueadas, reticulação da nervação fechada e na face adaxial dos folíolos pela nervação proeminente, além da presença de domácias urceoladas não salientes.

É proposta no presente trabalho a sinonimização do nome Matayba pallens sob M. elaeagnoides já que não foram encontrados caracteres que separem as duas espécies. Chama a atenção que Radlkofer (1934) posiciona como espécies afins a $M$. pallens as espécies $M$. juglandifolia e $M$. grandis por apresentarem uma rede de nervuras mais aberta do que a de M. elaeagnoides, além da ausência de domácias. Porém, no material observado, a rede de nervuras de $M$. pallens mostra-se idêntica, assim como as domácias que são tão frequentes quanto em $M$. elaeagnoides.

1.5. Matayba grandis Radlk., Sitzungsber. Math.Phys. Cl. Königl. Bayer. Akad. Wiss. München 9: 635. 1879. Tipo: BRASIL. RIO DE JANEIRO. Organ Mount. s/d, J.B.E. Pohl 678 (lectótipo W! [aqui designado]; isolectótipos BR!, F!, K!, M!).

Árvores, 5-6 m alt.; ramos cilíndricos, sulcados, subglabros a esparsamente pubescentes. Folhas dispersas por todo o ramo ou congestas no ápice; pecíolo 8,1-11,9 cm compr., cilíndrico a achatado, subglabros a esparsamente pubescentes; raque 14,5-31,6 cm compr., subcilíndrica a achatada, sulcada, subglabra a esparsamente pubescente; folíolos 6-8, peciólulos $0,6-1,1 \mathrm{~cm}$ compr., subcilíndricos a achatados, canaliculados, esparsamente pubescentes; lâmina 12-34,2 × 4,4-13,3 cm, largamente elípticos a elípticooblongos, cartáceos, planos, ápice agudo a levemente cuspidado, base obtusa a atenuada, simétrica; margem subrevoluta a plana, inteira; concolores, verde-escuros a verde-claros, as vezes pouco brilhantes, glabros a esparsamente pubescentes em ambas as faces; nervação esverdeada a castanho-esverdeada, proeminente na face adaxial, reticulação fechada; nervura central proeminente a plana na face adaxial, esparsamente pubescente em ambas as faces; nervação secundária eucamptódroma, 12-22 pares, levemente impressas na face adaxial oblíquas, arqueadas a curvadas; domácias ausentes. Inflorescências axilares, mais compridas que as folhas; pedúnculo 12,5-16,1 cm compr., cilíndrico a achatado, pubescente (densamente), raque $18,4-48,3 \mathrm{~cm}$ compr., achatada, pubescente (densamente). Flores 2-10 mm compr.; pedicelo 2-5 mm compr., articulado na região basal, densamente pubescente; sépalas ca.1,5 mm compr., ovaladas ou triangulares, livres a partir da região mediana, lobos ca.0,7 mm compr., ápice agudo; esparsamente pubescentes na face abaxial, lanosa na face adaxial, margem ciliada; pétalas $1-1,5 \mathrm{~mm}$ compr., obovadas (largamente), ápice obtuso a arredondado, erodido a levemente cuspidado, (sub)glabras na face abaxial, lanosas na face adaxial; base unguiculada; apêndice petalífero basal menor ou igual que a pétala, lanoso; disco nectarífero glabro; fl. masc.: estames ca. $3 \mathrm{~mm}$ compr., filetes iguais, sinuosos, densamente pubescentes até a região apical, anteras subglabras, pistilódio ca.1 mm compr., densamente pubescente; fl. fem.: estaminódios ca. $1 \mathrm{~mm}$ compr.; gineceu 2-3 mm compr., ovário ovalado, tricarpelar, levemente lobado, densamente pubescente; estilete 1-1,5 mm compr., estigma capitado, esparsamente pubescente. Cápsulas 1,5-2 $\times$ 1,2-1,7 cm, subglobosas, levemente lobadas, estípite ca. $1 \mathrm{~mm}$ compr., apiculadas; tricarpelares, 1-2 seminadas, epicarpo coriáceo, verrucoso a levemente tuberculado, pubérulo ou pubescente; endocarpo tomentoso, amarelado. Sementes desconhecidas.

Material examinado: BRASIL. BAHIA: Barro Preto, Serra da Pedra Lascada, 13,7 km de Barro Preto na estrada que passa pela fazenda São Miguel e sobe até o acesso a serra, caminhada ao topo da serra, 14 46' $13^{\prime \prime} \mathrm{S}$, 39³2'10'W, 2.XI.2003, bt., fl., P. Fiaschi et al. 1819 (CEPEC, SPF); Ilhéus, CEPLAC, área do CEPEC, atrás do Centro de Toxicologia, caminho a esquerda ca. $1 \mathrm{~km}$, fazenda vizinha, 10.I.2008, fr., R.O. Perdiz et al. 263 (CEPEC, SPF). MINAS GERAIS: Rio Novo, V.1896, fl., C.A.W. Schwacke 11975 (M). RIO DE JANEIRO: fl., J. Lhotskty (W); Rio de Janeiro, Vista Chinesa, perto da sede do Horto Florestal, 27.XII.1927, bt., fl. e fr., Pessoal do Horto Florestal RB564 (RB); Rio de Janeiro, caixa de água das obras públicas, 23.I.1932, bt., fl., P. Rosa RB443674 (RB); Rio de Janeiro, Jacarepaguá, Represa dos Ciganos, 8.XII.1921, fl., P. Ochioni 08 (CTES, ESA, RB). Rio de Janeiro, 1.XI.1940, bt., J.G. Kuhlmann ESA106499 (ESA, RB).

Matayba grandis é encontrada nas regiões nordeste (BA) e sudeste (MG - C.A.W. Schwacke 11975, RJ) do Brasil, e foi coletada com flores em dezembro e janeiro e frutos em dezembro. Embora $M$. grandis contenha caracteres como a rede de nervuras proeminente na face adaxial e reticulação fechada da nervação, assim como $M$. elaeagnoides, M. juglandifolia, M. leucodictya, M. obovata e $M$. stenodictya, esta espécie é reconhecida por apresentar nervação eucamptódroma ( $v s$. broquidódroma nas demais espécies). Além disso, o tamanho dos folíolos é outro caráter diagnóstico, 
já que em M. grandis podem alcançar até $34,2 \mathrm{~cm}$ de comprimento e 13,3 cm de largura.

Além dos sintipos, foram analisadas neste trabalho poucas coletas dessa espécie. O material Pohl 678 designado como lectótipo também pode ser encontrado também como uma coleta de Schott 5551 . Porém, após a observação do caderno de campo de Pohl, ficou confirmado que a coleta era sua.

1.6. Matayba guianensis Aubl., Hist. pl. Guiane fr. 1: 331, t. 128. 1775. Tipo: GUIANA FRANCESA. s/d, J.B.C.F. Aublet s/n. (holótipo BM!).

Ephielis fraxinea Willd., Sp. Pl. 2: 328. 1799. Tipo: GUIANA FRANCESA. s/d, J.B.C.F. Aublet $s / n$. (holótipo BM!). nom. illeg.

Matayba guianensis f. guianensis Radlk., Sitzungsber. Math.-Phys. Cl. Königl. Bayer. Akad. Wiss. München 9: 631. 1879. Tipo: BRASIL. Tipo: GUIANA FRANCESA. s/d, J.B.C.F. Aublet $s / n$. (holótipo BM!).

Matayba guianensis f. laxiflora Radlk., Sitzungsber. Math.-Phys. Cl. Königl. Bayer. Akad. Wiss. München 9: 632. 1879; Talisia laxiflora Benth., Hooker's J. Bot. Kew Gard. Misc. 2: 212. 1850. nom. illeg.; Cupania laxiflora (Benth.) Benth., Hooker's J. Bot. Kew Gard. Misc. 3: 198. 1851. Tipo: BRASIL. PARÁ. Santarém. s/d, R. Spruce 894 (lectótipo K! [aquí designado]; isolectótipos C!, M!, MPU!, W!).

Matayba guianensis f. micrantha (Mart.) Radlk., Sitzungsber. Math.-Phys. Cl. Königl. Bayer. Akad. Wiss. München 9: 632. 1879; Cupania micrantha Mart., Flora 21 (1. Beibl.). 1842. Tipo: BRASIL. PARÁ. Santarém. IX.1838. C.F.P. Martius 274 (lectótipo M! [aquí designado]; isolectótipo $\mathrm{K}$ !).

Matayba guianensis f. micrantha subf. pilosula Radlk., Sitzungsber. Math.-Phys. Cl. Königl. Bayer. Akad. Wiss. München 9: 632. 1879. Tipo: BRASIL. RIO DE JANEIRO. s/d, A.F.M. Glaziou 12503 (lectótipo $\mathrm{C}$ ! [aqui designado]).

Matayba guianensis f. micrantha subf. euphoriaefolia (Cambess.) Radlk., Sitzungsber. Math.-Phys. Cl. Königl. Bayer. Akad. Wiss. München 9: 633. 1879; Cupania euphoriaefolia Cambess., Fl. bras. Mer.1: 388. 1828. Tipo: BRASIL. A. St.-Hilaire $s / n$ (lectótipo MPU! [aqui designado]).

Matayba guianensis f. micrantha subf. acutata Radlk., Sitzungsber. Math.-Phys. Cl. Königl. Bayer. Akad. Wiss. München 9: 633. 1879. Tipo: BRASIL. MINAS GERAIS. Presídio de São João Batista. s/d, F. Sellow B2070 c2021 (lectótipo M! [aqui designado]).
Matayba guianensis f. micrantha subf. sublinearis Radlk., Sitzungsber. Math.-Phys. Cl. Königl. Bayer. Akad. Wiss. München 9: 633. 1879. Tipo: BRASIL. Lagoa Santa. s/d, E. Warming $s / n$ (lectótipo M! [aqui designado]; isolectótipos BR!, C!). Matayba guianensis f. fuscescens Radlk., Sitzungsber. Math.-Phys. Cl. Königl. Bayer. Akad. Wiss. München 9: 632. 1879. Tipo: BRASIL. RIO DE JANEIRO. s/d, J.B.E. Pohl 1948 (lectótipo W! [aqui designado]; isolectótipo BR!).

Matayba guianensis f. livescens subf. verrucosa Radlk., in Mart., Fl. bras. 13(3): 622. 1900. Tipo: BRASIL. MINAS GERAIS. Santa Luzia do Rio das Velhas. XI.893. A.F.M. Glaziou 20239 (lectótipo M! [aqui designado]; isolectótipo C!). Matayba steinbachii Melch., Notizbl. Bot. Gart. Berlin-Dahlem 10: 349. 1928. Tipo: BOLÍVIA. SANTA CRUZ. Sara, Buenavista. 15.VIII.1924. R.F. Steinbach 6301 (holótipo B; isótipos G!, GOET!, K!, MO!).

Talisia prancei Guarim, Acta Amazon. 9(2): 235239, f. 3. 1979. Tipo: BRASIL. GOIÁS. Serra do Caiapó. $40 \mathrm{~km}$ south of Caiaponia. 25.X.1964. G.T. Prance \& N.T. Silva 59651 (holótipo NY!; isótipos B!, F!, GH, HT!, IT, MO!, S!, US!). Fig. 3

Árvores ou arbustos, 1-10 m alt.; ramos cilíndricos, glabros a pubescentes. Folhas dispersas por todo o ramo; 1,1-6,1 cm compr., pecíolo (sub) cilíndrico, subglabro a pubescente; raque 1-21,5 cm compr., (sub)cilíndrica, bicanaliculada ou levemente costada, subglabra a pubescente; folíolos 2-12, subsésseis ou peciólulos $0,3-0,6 \mathrm{~cm}$ compr., cilíndricos a clavados, esparsamente pubescentes; lâmina 3,5-17,3 × 1,6-6,2 cm, elípticos, elípticolanceolados, elíptico-obovados, elíptico-oblongos, elíptico-ovados, ovados (largamente), cartáceos, geralmente conduplicados, geralmente recurvados, ápice agudo, obtuso a arredondado ou levemente cuspidado, base aguda, atenuada a obtusa, simétrica a assimétrica; margem revoluta, inteira, às vezes ondulada; concolores, castanho-claros, castanho-esverdeados a verde-claros, subglabros a pubescentes na face abaxial, verde-acinzentados, castanho-escuros, castanho-acinzentados, castanho-avermelhados a castanho-esverdeados, subglabros na face adaxial; nervação castanhoamarelada a castanho, inconspícua na face adaxial, reticulação aberta; nervura central proeminente, subglabra a densamente pubescente em ambas as faces; nervação secundária broquidódroma, 6-12(-14) pares, levemente proeminentes na face adaxial, oblíquas, geralmente curvadas, raramente arqueadas; domácias presentes, geralmente 


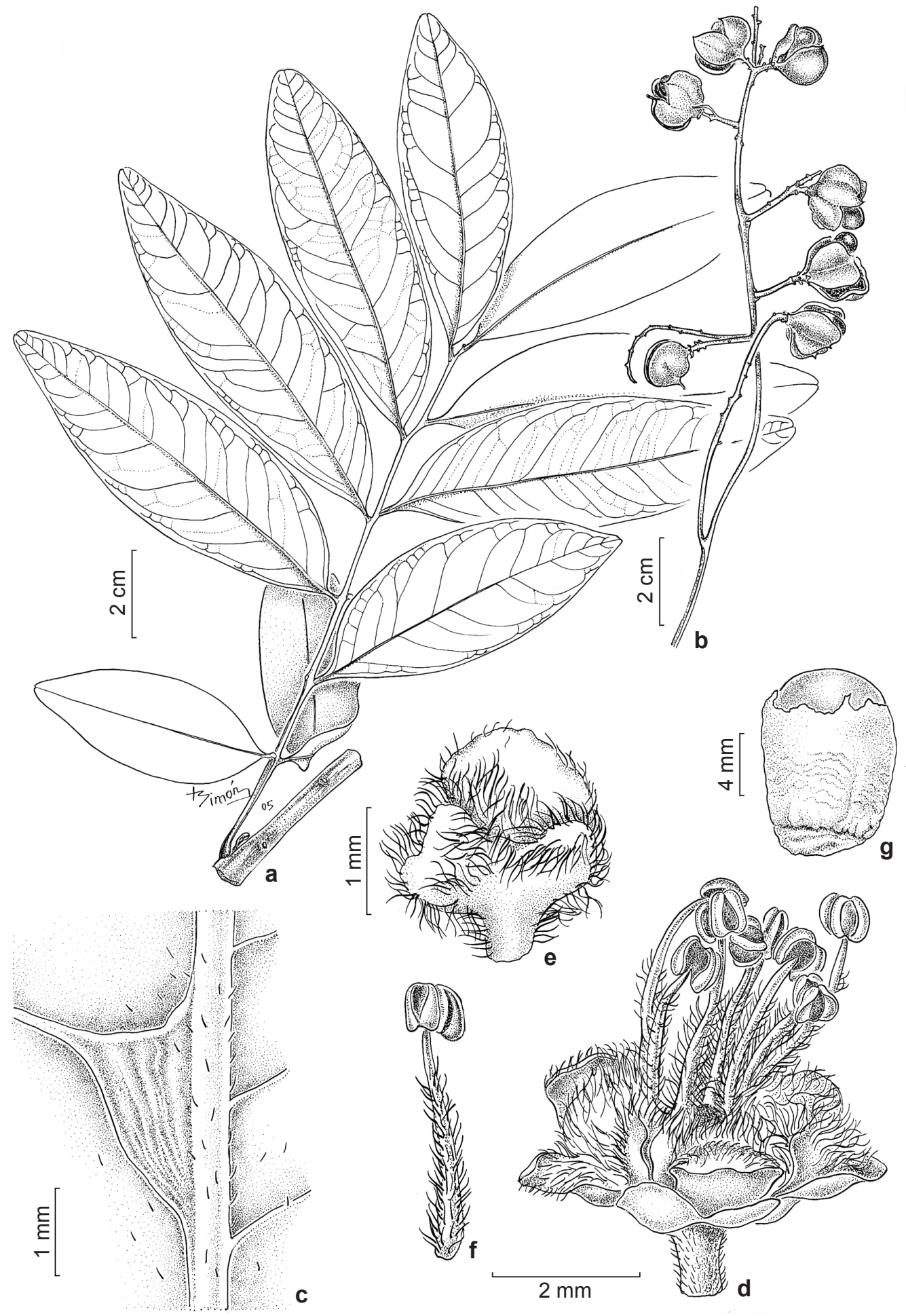

Figura 3 - Matayba guianensis Aubl. - a. ramo; b. inflorescência; c. detalhe da face abaxial do folíolo mostrando uma domacia urceolada; d. flor estaminada; e. pétala, face interna; f. estame da flor estaminada; g. semente. [a,g. Pereira Neto \& Lopes 573 (CTES); b. Walter 2338 (CEN); c. Walter 525 (CTES); d-f. Vieira et al. 1673 (CTES)]. Figure 3 - Matayba guianensis Aubl. - a. branch; b. inflorecence; c. detail of abaxial surface showing an urceollate domatia; d. staminate flower; e. petal inner face; f. stamen of pistillate flower; g. seed. [a,g. Pereira Neto \& Lopes 573 (CTES); b. Walter 2338 (CEN); c. Walter 525 (CTES); d-f. Vieira et al. 1673 (CTES)]. 
1-3 por folíolo, urceoladas ou foveoladas, não proeminentes na face adaxial dos folíolos. Inflorescências axilares ou terminais; geralmente mais curtas que as folhas, raramente mais compridas, pedúnculo 6-14,1 cm compr., achatado, glabros a esparsamente pubescentes, raque 3-21,3 cm compr., achatada, sulcada, pubescente (densamente). Flores 5-7 mm compr.; pedicelo 1-2 mm compr., articulado na região basal ou central, pubescente sépalas 1-2 mm compr., ovaladas (largamente), livres a partir das regiões basal ou mediana, lobos $0,7-1,5 \mathrm{~mm}$ compr., ápice obtuso, arredondado ou raramente agudo, (esparsamente/ densamente) pubescentes na face abaxial, (sub) glabras na face adaxial, margem ciliada; pétalas 1-2 mm compr., ovaladas, oblongas, obovadas a obovado-oblongas, raramente espatuladas, ápice arredondado a retuso, raramente agudo, irregular a truncado, subglabras na face abaxial, lanosas na face adaxial; base unguiculada, apêndice petalífero basal menor ou de mesmo tamanho que as pétalas, lanoso; disco nectarífero glabro; fl. masc.: estames 2-4 mm compr., filetes iguais ou desiguais, retos ou levemente sinuosos, densamente pubescentes na região basal, esparsamente pubescentes a pubescentes na central e (sub) glabros na apical, anteras subglabras, pistilódio 0,8-2 mm compr., (densamente) pubescente; fl. fem.: estaminódios ca. $1 \mathrm{~mm}$ compr.; gineceu 2-6 mm compr., ovário ovalado a piriforme, levemente lobado, densamente pubescente; estilete 1-3 mm compr., estigma bífido ou trífido, subglabro a pubescente. Cápsulas $0,7-1 \times 0,6-1,5 \mathrm{~cm}$, globosas, levemente lobadas a fortemente lobadas, estípite inconspícua ou raramente de 1-2 mm compr., apiculadas, bicarpelares a tricarpelares, geralmente (1-)3-seminados, raramente 1-2-seminados; epicarpo coriáceo, subverrucoso a tuberculado, subglabro a densamente pubérulo; endocarpo tomentoso, esbranquiçado a ferrugíneo. Sementes 0,5-1,1 ×0,4-0,7 cm, elipsoides, ovóides, oblongas a obovadas; arilo esbranquiçado recobrindo até a região apical da semente.

Nomes populares: brazeiro, camboatá, camboatã, camboatá-branco, olho-de-cotia, mataíba, batabaíba, cuvantã, jatuá-uba, jatuá-iba, pau-dadigestão, atou-aou, tou-aou, canela-de-negro.

Material selecionado: BOLÍVIA. SANTA CRUZ: Nuflo de Chávez, La Pachanga, $5 \mathrm{~km} \mathrm{~S}$ of Concepción, 26.XI.1986, fl., T. Killeen 2237 (F, SP). BRASIL. AMAZONAS: Manaus, Cachoeira baixa de Tarumã, 12.IX.1986, fl., G.T. Prance 2270 (NY, R). CEARÁ: Barbalha, Floresta Nacional do Araripe, 10.X.2001, fr., I.R. Costa 767 (UB). DISTRITO FEDERAL: Brasília, bacia do rio São Bartolomeu, 5.XI.1979, fl., E.P. Heringer 2693 (IBGE, K, MO, NY, RB, US). ESPÍRITO SANTO: Marechal Floriano, Bom Jesus, 21.X.2000, fl., G. Hatschbach 71499 (MBM). GOIÁS: 1867, fl., W.J. Burchell 6583 (BR); fl., Gardner 3074 (W); Pirenópolis, Serra dos Pirineus, 19,5 km do trevo de Anápolis e Goiânia em direção ao Parque, 19.I.2005, fr., M.S. Ferrucci 3222 (ESA, PORT, UFG). MARANHÃO: São Luís, Reserva Florestal do Sacavem, 13.VIII.1992, fl., F.H. Muniz 208 (HRCB, INPA, RB, UB). MATO GROSSO: Barra do Garças, Serra do Taquaral, fazenda Taquaral, 26.XI.1997, bt., L.C. Bernacci 2619 (CTES, ESAIAC, MT). MATO GROSSO DO SUL: Aquidauana, Serra de Maracaju, Estação Repetidora da TELEMS, 5.II.1998, fr., O.S. Ribas 2523 (BHCB, ESA, HUCS, MBM, SP, SPF). MINAS GERAIS: fl., A.F.M. Glaziou 10421 (C); fl., A.F.M. Glaziou 10426 (C, S); fl., A.F.M. Glaziou 13634 (C); fl., A.F.M. Glaziou 20863 (C, S); Botumirim, saída sul da cidade, 18.XI.1992, fr., $R$. Mello-Silva 704 (CTES, MBM, RB, SPF, UB); Queluz, 1881, fl., A.F.M. Glaziou 20863 (C, S); Santa Luzia do Rio das Velhas, XI.893, fl., C.A.W. Schwacke 9618 (M). Uberaba, 18.II.1848, fl., A.F. Regnell III356 (C, S). PARÁ: Alenquer, estrada Lauro Sodré, faz. Buraco D'água, 28 km de Alenquer, 2.XI.1987, fr., C.A. Cid Ferreira 9383 (INPA, NY, RB); Santarém, VI.1850, fl., R. Spruce 894 (K); Santarém, 1859, fl., L. Riedel 1563 (BR). PARAIIBA: Serra do Araripe, VIII.1927, fl., v. Luetzelbarg 12522 (R). RONDÔNIA: Mutumparaná, track from Mutumparaná to Rio Madeira, 30.IX.1968, fr., G.T. Prance 8993 (A, C, COL, F, G, INPA, K, M, MG, MICH, MO, NY, P, R, S, VEN, U, US). RIO DE JANEIRO: fl., A.F.M. Glaziou 9368 (BR, C P); fl., A.F.M. Glaziou 11606 (BR, C); fl., A.F.M. Glaziou 17495 (sintipo C!); 1883, fl., A.F.M. Glaziou 12502 (BR); fl., Pohl 1972 (W); Rio de Janeiro, fl., A.F.M. Glaziou 6493 (C, S); Rio de Janeiro, fl., A.F.M. Glaziou 1587 (C, S). SÃO PAULO: Avanhandava, margem da estrada Avanhandava-Barbosa, a ca. $8 \mathrm{~km}$ de Barbosa, 4.VII.1994, fl., J.R. Pirani 3178 (HRCB, PMSP, SP, SPF, UEC); Franca, in circuitu urbis Franca ad confines prov. Minas Gerais, 1902, fl., L. Wacket (W19080004071). TOCANTINS: Corrente, $\mathrm{Km} 7$ da estrada de Corrente, 5.XII.1991, fl., B.A.S. Pereira 1982 (IBGE, K, MO). VENEZUELA. APURE: Otto Muñoz, Hato "El Polvero", $79 \mathrm{~km}$ al S de Elorza, 30.IV.1987, fl., G. Aymard 5741 (PORT, SP).

Matayba guianensis encontra-se amplamente distribuída na América do Sul. No Brasil ocorre em quase todo o território, embora tenha limite sul no Paraná. Ocorre na maioria das formações vegetacionais brasileiras, porém prevalecendo nos cerrados e em matas ciliares. Essa espécie é encontrada também em campos rupestres, em matas paludosas, semidecíduas, ombrófila e em sua transição com os cerrados, em altitudes que 
variam entre 350 a 1200 metros. Foi coletada com flores em praticamente todos os meses do ano, e com frutos nos meses de outubro a fevereiro, abril e junho.

Morfologicamente, M. guianensis pode ser facilmente diferenciada das demais espécies pela coloração castanha dos folíolos que são geralmente recurvados e conduplicados, com nervação inconspícua na face adaxial, reticulação aberta e nervuras secundárias curvadas. Radlkofer (1879, 1934) reconheceu cinco formas de $M$. guianensis, duas destas divididas em quatro e duas subformas respectivamente. Porém, toda essa variação citada pelo autor (1934) é visivelmente contínua e após a análise de um maior número de materiais, foram incluídas como sinônimos de $M$. guainensis, exceto M. livescens (M. guianensis f. livescens), que foi reconhecida como uma espécie por Coelho et al. (2014).

1.7. Matayba heterophylla (Mart.) Radlk., Sitzungsber. Math.-Phys. Cl. Königl. Bayer. Akad. Wiss. München 9: 634. 1879; Cupania heterophylla Mart., Flora 21 (2 Biebl.): 69. 1838. Tipo: BRASIL. BAHIA. Serra dos Lages em Sincorã. s/d, C.F.P. Martius s/n (lectótipo M! [aqui designado]).

Fig. 4

Árvores ou subarbustos, 0,5-6 m alt.; ramos subcilíndricos a cilíndricos, glabros a pubescentes. Folhas dispersas por todo o ramo ou congestas nos ápices, pecíolos 1,2-5,3 cm compr., subcilíndricos, subglabros a pubescentes; raque $(1,5) 3,1-8,3(9,6)$ cm compr., subalada ou marginada, glabra a pubescente; folíolos 4-10, subsésseis; lâmina $1,1-7,9 \times 0,6-3,4 \mathrm{~cm}$, geralmente ovados e elípticos, raramente lanceolados ou oblongos, subcartáceos a cartáceos, planos, ápice acuminado a agudo, raramente obtuso a mucronado, base clavada, simétrica, margem plana, serrulada a raramente serreada; concolores, verde-claros, verde-escuros ou castanho, (sub)glabros em ambas as faces; nervação esbranquiçada, castanho a castanho-esverdeada, inconspícua a proeminente na face adaxial, reticulação aberta; nervura central proeminente na face adaxial, (sub)glabra em ambas as faces; nervação secundária geralmente craspedódroma ou raramente eucamptódroma, 6-10 pares, proeminentes na face adaxial, geralmente oblíquas, raramente perpendiculares, geralmente arqueadas ou curvadas, raramente retilíneas; domácias presentes, urceoladas ou foveoladas, salientes na face adaxial dos folíolos. Inflorescências axilares ou terminais, mais curtas que as folhas; pedúnculo 0,5-3 mm compr., achatado, pubescente; raque 0,4-6,3 mm compr., achatada, pubérula a pubescente. Flores 5-8 mm compr.; pedicelo 3-4 mm compr., articulado na região apical, pubescente; sépalas 1,5-2,5 mm compr., ovaladas, livres a partir da base, lobos 1-2 mm compr., ápice acuminado a agudo; (sub) glabras em ambas as faces; pétalas 0,5-1,5 mm compr., ovaladas a obovadas, ápice acuminado a levemente emarginado, (sub)glabras em ambas as faces, geralmente com margem ciliada; base unguiculada, apêndice petalífero basal geralmente maior, raramente menor que a pétala, viloso; disco nectarífero glabro; fl. masc.: estames 3-5 mm compr., filetes iguais, retos a levemente sinuosos, pubescentes na região basal, anteras glabras; pistilódio 0,5-1 $\mathrm{mm}$, tomentoso; fl. fem.: estaminódios 1-2 mm compr.; gineceu 2-3 mm compr., ovário elipsóide, densamente pubescente, estilete ca.1 $\mathrm{mm}$ compr., estigma capitado, subtomentoso a tomentoso. Cápsulas 1-2,5 × 0,4-1,4 cm, turbinadas, levemente lobadas, estípite 4-8 mm compr., apiculadas; bicarpelares ou tricarpelares, 1-seminadas, epicarpo subcoriáceo, subverrucoso a verrucoso, glabro a esparsamente pubescente; endocarpo tomentoso, esbranquiçado a amarelado. Sementes $0,5 \times 1,2 \mathrm{~cm}$ compr., oblongas; arilo alvo a amarelado recobrindo totalmente a semente.

Nomes populares: pitombeira.

Material selecionado: BRASIL. BAHIA: Abaíra, Salão, $9 \mathrm{~km}$ de Catolés na estrada para Inúbia, 28.XII.1991, fr., R.M. Harley 50532 (CTES, HUEFS, K, SPF); Água Quente, Pico das Almas, vertente oeste, entre Paramirim das Crioulas e a face NW do pico, 17.XII.1988, fr., R.M. Harley 27582 (CEPEC, CTES, K, SPF, UEC); Chapada Monte Alegre, X.1912. fl., Zehntner 4029 (M); Rio de Contas, Pico das Almas, vertente leste, perto da fazenda Brumadinho, $16 \mathrm{~km} \mathrm{N-O}$ da cidade, 27.XI.1988, bt., fl., R.M. Harley 27008 (CEPEC, HUEFS, K, NY, SP, SPF, UB). GOIÁS: Guarani de Goiás, estrada PosseGuarani de Goiás, 18 km norte da estação rodoviária de Posse, 4.XII.2003, fr., R.C. Forzza 2566 (RB, SPF); São Domingos, Km 34 da estrada Guaraní de Goiás-Terra Ronca, 23.XI.1996, fr., B.A.S. Pereira 3294 (IBGE, K, NY, RB, UFG). MARANHÃO: Caxias, BR-316, between Caxias and Timon, $39 \mathrm{~km}$ SE of Caxias and ca. $37 \mathrm{~km}$ NW of Teresina, 24.I.1983, fr., W. Thomas 9585 (CTES, NY); Mirador, entre Mirador e Colinas, 3.XI.1985, fr., $A$. Fernandes (EAC13906, ESA107548). MINAS GERAIS: Formigas, inter Formigas et Contendas in campis consitis Sertão dictis, in Tabuleiro versus Chapada do Paranán, IX., fl., C.F.P. Martius (M); Formoso, Parque Nacional Grande Sertão Veredas, nascente do rio Preto, vereda do Veado, 16.X.1997, fr., D. Alvarenga 982 (EAC, 


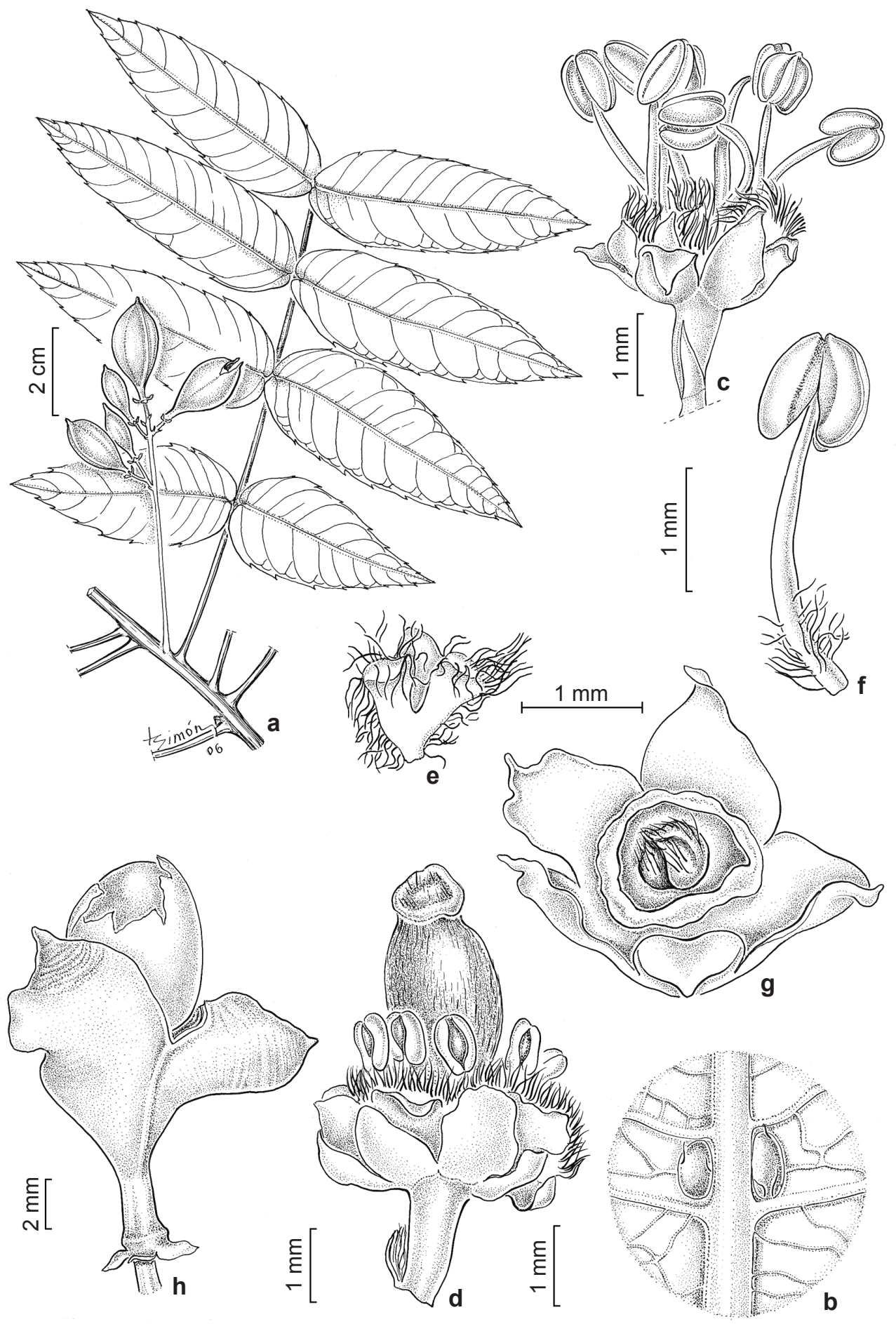

Figura 4 - Matayba heterophylla (Mart.) Radlk. - a. ramo com frutos; b. detalhe da face abaxial mostrando uma domacia foveolada; c. flor estaminada; d. flor pistilada; e. pétala, face interna; f. estame da flor estaminada; g. flor estaminada sem a corola e androceu mostrando o disco nectarífero e o pistilódio. [a. Azevedo et al. 1231 (CTES); b. Ganev 2439 (CTES); c,e-g. Harley et al. 26091, Queiroz \& Nascimento 3599 (CTES)].

Figure 4 - Matayba heterophylla (Mart.) Radlk. - a. branch with fruits; b. detail of the abaxial surface showing a pit domatia; c. staminate flower; d. pistillate flower; e. petal inner face; $\mathrm{f}$. stamen in pistillate flower; g. staminate flower lacking corolla and androecium showing nectar disc and pistillode. [a. Azevedo et al. 1231 (CTES); b. Ganev 2439 (CTES); c,e-g. Harley et al. 26091, Queiroz \& Nascimento 3599 (CTES)]. 
IBGE, NY, RB). PERNAMBUCO: Santa Rita, Rio Preto, IX.1839, fl., G. Gardner 2800 (K000586103). PIAUÍ: 1841, fl., G. Gardner 2800 (K000586104); Manoel Emídio, Riacho Caldeirão, 28.XI.1979, fl., S. de Assis 270 (IPA, SPF). PIAUÍ: Teresina, Parque Piauí, 21.XII.1980, fr., F. Chagas e Silva IBGE9896 (IBGE, K, NY). TOCANTINS: Araguatins, 19.XI.1983, fr., $E$. Mileski 369 (RB).

Matayba heterophylla é encontrada nos estados do norte (TO), nordeste (BA, PE, PI, $\mathrm{MA})$, centro-oeste (GO) e sudeste (MG), em formações abertas como campos rupestres e nos cerrados, além de capoeiras, carrascos de encosta e áreas de transição entre as veredas e os cerrados, geralmente em solo arenoso ou rochoso. A altitude onde foi coletada varia de 600 a 1260 metros. Encontrada com flores nos meses de setembro a novembro e frutos de setembro a janeiro e maio.

Essa é a única espécie desta seção que apresenta a margem dos folíolos serrulada a serreada, as domácias salientes na face adaxial dos folíolos, as cápsulas turbinadas com estípites que medem de 4-8 mm compr., e que são sempre unisseminadas. A semelhança com outras espécies se deve a apenas dois caracteres. Primeiro, a raque das folhas subalada também ocorre em $M$. marginata, porém esta apresenta a margem dos folíolos inteira e segundo, algumas vezes $M$. heterophylla apresenta a nervação eucamptódroma assim como $M$. grandis (que também apresenta a margem dos folíolos inteira e ausência de domácias).

1.8. Matayba intermedia Radlk. in Martius, Fl. bras. 13(3): 619. 1900. Tipo: BRASIL. RIO DE JANEIRO. VIII.1877. A.F.M. Glaziou 8607. (lectótipo R! [aqui designado]; isolectótipos C!, $\mathrm{F}$ !, K!, P!).

Árvores ou arbustos, 2-30 m alt.; ramos cilíndricos a achatados, subglabros a esparsamente pubescentes. Folhas dispersas por todo o ramo ou congestas no ápice; pecíolo 1-4,1 cm compr., (sub)cilíndrico, subglabros a pubescentes; raque 1,1-12,6 cm compr., subcilíndrica, bicanaliculada, subglabra a pubescente; folíolos 4-12, subsésseis ou peciólulos $0,2-0,7 \mathrm{~cm}$ compr., canaliculados, pubérulos a pubescentes; lâmina 2,3-11,7 × 0,9-4,1 cm, cartáceos, oblongos, elípticooblongos, obovados, elíptico-obovados, obovadooblongos, elípticos, elíptico-lanceolados a elíptico-ovalados; planos, ápice agudo, obtuso, arredondado ou retuso, raramente levemente cuspidado, base aguda, atenuada ou raramente obtusa, assimétrica ou simétrica; margem revoluta, inteira, ou ondulada; discolores, castanho-claros a vináceos, (sub)glabros na face abaxial, verde-acinzentados a verde-amarelados, brilhantes, (sub)glabros na face adaxial; nervação verde-acinzentada, verde-amarelada a castanhoavermelhada, inconspícua a plana na face adaxial, reticulação aberta; nervura central levemente proeminente a impressa face adaxial, glabra a esparsamente pubescente em ambas as faces; nervação secundária broquidódroma, 8-16 pares, levemente proeminentes na face adaxial, geralmente oblíquas, raramente perpendiculares, geralmente retilíneas, raramente levemente arqueadas; domácias ausentes. Inflorescências axilares; geralmente mais curtas, raramente mais compridas; pedúnculo 0,6-11,9 cm compr., subcilíndrico a achatado, subglabro a densamente pubescente, raque 0,9-15,4 cm compr., achatada, pubérula a densamente pubescente. Flores 6-8 mm compr.; pedicelo 2-3 mm compr., articulado na região basal, densamente pubescente; sépalas 1-1,5 mm compr., ovaladas, livres a partir das regiões basal ou mediana, lobos 0,7-1,2 mm compr., ápice agudo a obtuso; (esparsamente) pubescentes na face abaxial, glabras a pubescentes na face adaxial, margem ciliada; pétalas 1-2 mm compr., obovadas a ovaladas, ápice obtuso, arredondado a retuso, irregular a levemente cuspidado, (sub)glabras na face abaxial, lanuginosas a lanosas na face adaxial; base unguiculada., apêndice petalífero basal menor, igual ou maior que as pétalas, lanoso; disco nectarífero glabro; fl. masc.: estames $2-4 \mathrm{~mm}$ compr., filetes geralmente desiguais, raramente iguais, retos ou sinuosos, densamente pubescentes até a região central e esparsamente pubescentes na região apical, anteras glabras, pistilódio ca.1 mm compr., densamente pubescente; fl. fem.: estaminódios ca.1,5 mm compr.; gineceu 3-4 $\mathrm{mm}$ compr., ovado, estilete 1-1,5 mm compr., estigma trífido, (esparsamente) pubescentes (densamente). Cápsulas 0,6-1,7 × 0,7-1,4 cm, globosas, levemente lobadas, estípite ca.1 mm compr., apiculados; bicarpelares a tricarpelares, raramente tetracarpelares, 1-3 seminadas, epicarpo coriáceo, subverrucoso, (esparsamente a densamente) pubérulo; endocarpo densamente tomentoso, esbranquiçado a amarelado. Sementes ca. $1 \times 0,4 \mathrm{~cm}$ compr., oblongas, obovóides ou ovóides; arilo alvo a amarelado recobrindo até a região apical da semente.

Nomes populares: camboatá, camboatã-defolha-meuda, mataíba. 
Material selecionado: BRASIL. PARANÁ: Guaraqueçaba, Tabagaça de Cima, rio Tabagaça, 20.XI.2003, fl., G. Hatschbach 76728 (HUCS, MBM, RB, SPF); Guaratuba, rio da Divisa, 11.XI.1963, bt., G. Hatschbach 9470 (HAS, MBM). RIO GRANDE DO SUL: Sapucaia, Sapucaia para São Leopoldo, 16.IX.1954, bt., fl., B. Rambo (PACA 37918); Torres, Perdida, 17.XI.1992, fl., J.A. Jarenkow 2199 (ESA, ICN, MBM, PEL). RIO DE JANEIRO: fl., C.A.W. Schwacke 4829 (B); Angra dos Reis, Ilha Grande, Reserva Biológica Estadual da Praia do Sul, 19.IX.1991, fl., D.S.D. Araújo 9463 (GUA); Ilha da Marambaia, Praia Grande, 19.XI.1987, fr., A.A.M. de Barros 174 (R); Rio de Janeiro, Floresta da Tijuca. fl., A.F.M. Glaziou 11821 (K, P); Rio de Janeiro, restinga de Jacarepaguá, ao lado norte da pedra de Itaúna, 30.IX.1969, fr., D. Sucre 5992 (PACA, RB). SANTA CATARINA: Araranguá, Sombrio para Araranguá, 16.IX.1954, fl., R. Reitz 1267 (PACA); Itajaí, Morro da Ressacada, 18.XI.1955, fl., R.R. Klein 1780 (HBR, MBM, PACA); Rio do Sul, Matador, 16.X.1958, fl., R. Reitz 7247 (HBR, PACA). SÃO PAULO: Pariquera-Açu, propriedade de Antônio Povinski, 12.XI.1995, fl., N.M. Ivanauskas 555 (ESA, HRCB, UEC); São Miguel Arcanjo, Parque Estadual Carlos Botelho, 20.I.1992, fr., P.L.R. de Moraes 649 (ESA, SPSF); São Paulo, Horto Florestal, (fl.), 15.X.1946, D.B.J. Pickel SPSF2785 (SPSF).

Matayba intermedia encontra-se distribuída no estados das regiões sul (PR, RS e SC) e sudeste (RJ, SP) principalmente nas florestas ombrófilas densas nas encostas de morros ou menos comumente em altitudes mais baixas, em margens de rios ou ainda em planícies alagadas. No Rio de Janeiro, M. intermedia é encontrada com mais frequência nas florestas de restinga. Esta espécie é encontrada entre 5 e 850 metros de altitude. Coletada com flores de junho a novembro e com frutos de novembro a fevereiro e raramente em julho.

Matayba intermedia é frequentemente confundida com $M$. elaeagnoides, porém em M. intermedia a nervação é inconspícua ou praticamente plana na face adaxial dos folíolos, a reticulação é aberta, as nervuras secundárias são retilíneas e os folíolos não apresentam domácias, contra a nervação proeminente na face adaxial dos folíolos, reticulação fechada, nervuras secundárias arqueadas e a presença de domácias em M. elaeagnoides. Relacionadas ainda a $M$. intermedia por apresentar a nervação inconspícua com reticulação aberta e nervuras secundárias geralmente retilíneas estão outras duas espécies: M. boliviana e $M$. discolor. Matayba boliviana ocorre apenas na Bolívia e se diferencia por caracteres relacionados a partes do gineceu como o estigma, por exemplo (ver comentários para $M$. boliviana), enquanto $M$. discolor, diferencia-se não apenas pelas características já citadas (ver os comentários para $M$. discolor), como também por não apresentarem a mesma distribuição geográfica no Brasil.

1.9. Matayba juglandifolia (Cambess.) Radlk., Sitzungsber. Math.-Phys. Cl. Königl. Bayer. Akad. Wiss. München 9: 635. 1879; Sapindus juglandifolius Cambess., in St. Hilaire, Fl. bras. Mer. 1: 391. 1825. Tipo: BRASIL. RIO DE JANEIRO. Ubá. s/d, A. St. Hilaire 487 (holótipo P!).

Fig. 5

Árvores 3-15 m alt.; ramos cilíndricos a achatados, (sub)glabros. Folhas dispersas por todo o ramo ou congestas no ápice; pecíolo 1,8-7,5 cm compr., (sub)cilíndrico, glabro a esparsamente pubescente; raque 2,2-19,4 cm compr., subcilíndrica a bicanaliculada, subglabra a esparsamente pubescente; folíolos 4-10, subsésseis ou peciólulos 0,2-0,8 cm compr., canaliculados a clavados, subglabros; lâmina 3,9-19 × 1-7 cm, obovados, elíptico-obovados, obovado-oblongos, largamente obovados, oblanceolados ou oblongos, cartáceos, planos, ápice arredondado, obtuso ou retuso, raramente agudo, base aguda a atenuada, simétrica a assimétrica; margem subrevoluta a revoluta, inteira; concolores, verde-claros, verdeamarelados ou verde-escuros, as vezes brilhantes na face adaxial, (sub)glabros em ambas as faces; nervação esbranquiçada a amarelada, proeminente na face adaxial, reticulação fechada; nervura central proeminente a plana na face adaxial, glabra em ambas as faces; nervação secundária broquidódroma, (5-)8-16 pares, proeminentes na face adaxial, geralmente oblíquas, raramente perpendiculares; retilíneas; domácias geralmente ausentes ou raramente presentes, urceoladas, não salientes na face adaxial dos folíolos. Inflorescências axilares, mais curtas que as folhas; pedúnculo 1,49,8 cm compr., cilíndrico a achatado, subglabro, raque $8,5-20,5 \mathrm{~cm}$ compr., achatada, subglabra a densamente pubescente. Flores 7-10 mm compr.; pedicelo 2-3 mm compr., articulado geralmente na região basal, raramente nas regiões central e apical, densamente pubescente; sépalas 1,5-2 mm compr., ovaladas, livres a partir da base, 1-1,5 mm compr., ápice geralmente agudo, raramente obtuso ou arredondado; esparsamente pubescente na face abaxial, subglabra a esparsamente pubescente na face adaxial, margem ciliada; pétalas $1-2 \mathrm{~mm}$ compr., obovadas, ovaladas, rombóides, ápice, 


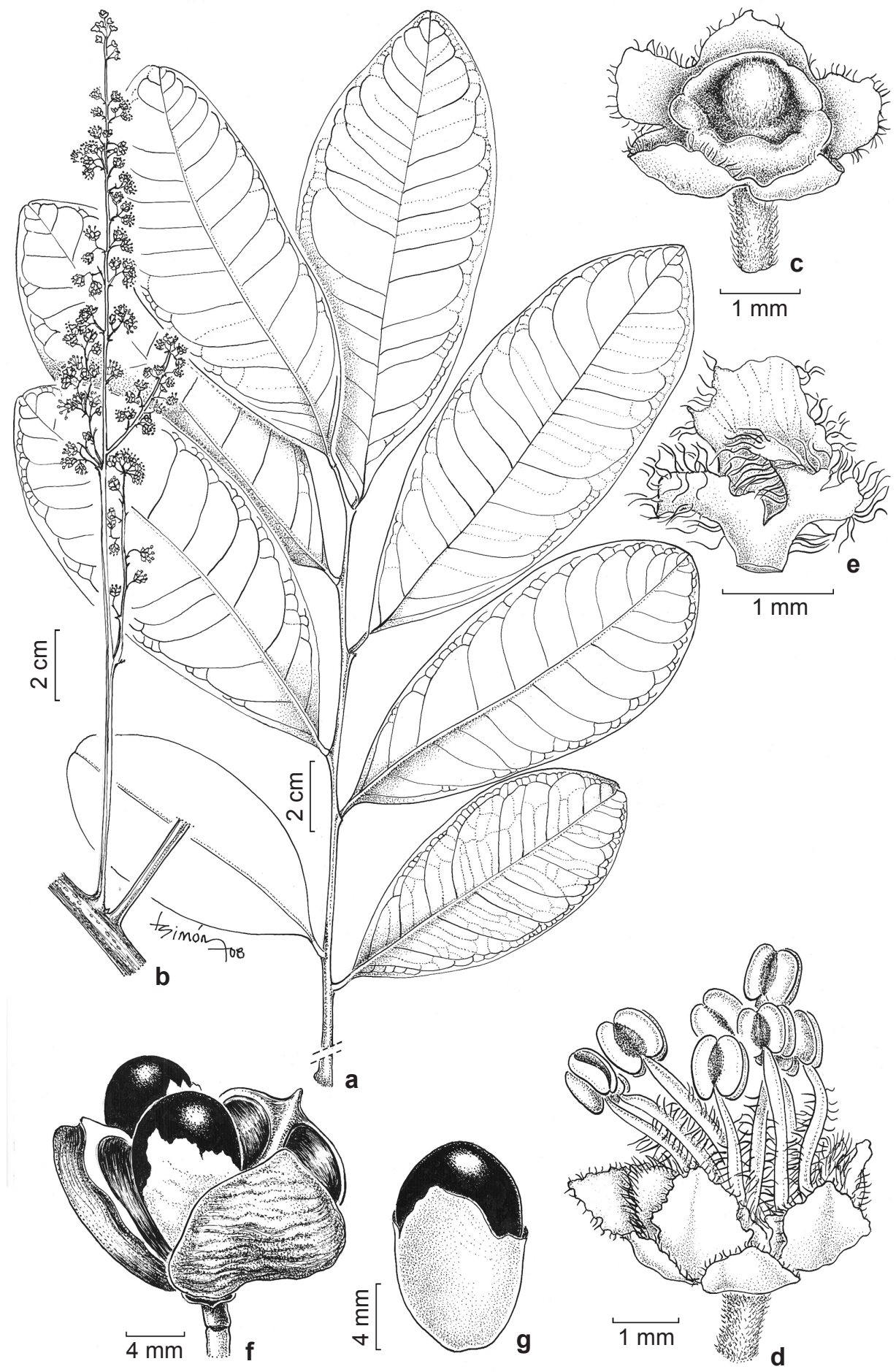

Figura 5 - Matayba juglandifolia (Cambess.) Radlk. - a. folhas; b. parte de ramo com inflorescência; c. flor sem pétalas e estames, mostrando o disco nectarífero; d. flor estaminada; e. pétala, face adaxial; f. fruto; g. semente. [a-e. Assis e Magalhães 583 (CTES); f,g. Ferreira \& Pivari 401 (CTES)].

Figure 5 - Matayba juglandifolia (Cambess.) Radlk. - a. leaves; b. branch with inflorescence; c. flower lacking corolla and androecium showing nectar disc; d. staminate flower; e. petal, inner face; f. fruit; g. seed. [a-e. Assis e Magalhães 583 (CTES); f,g. Ferreira \& Pivari 401 (CTES)]. 
obtuso, retuso ou raramente agudo, irregular, (sub)glabras na face abaxial, lanosas na face adaxial; base unguiculada, apêndice petalífero basal menor ou de mesmo tamanho que a pétala, lanoso; disco nectarífero glabro; fl. masc.: estames 3-5 mm compr., filetes iguais ou desiguais, sinuosos, densamente pubescentes na região basal, esparsamente pubescente nas regiões central e apical, anteras glabras, pistilódio 1-1,5 mm compr., densamente pubescente; fl. fem.: estaminódios 1-1,5 mm compr.; gineceu 5-7 mm compr., ovalado-oblongo, levemente lobado, densamente pubescente; estilete ca. $3 \mathrm{~mm}$ compr., estigma capitado, esparsamente pubescente. Cápsulas 0,8-2,7 × 0,6-2,5 cm, ovóides, globosas, levemente lobadas, estípite 1-3 mm compr., apiculados; bicarpelares ou tricarpelares, 1-2-3 seminadas, epicarpo subcoriáceo a coriáceo, subverrucoso a verrucoso, raramente tuberculado, esparsamente a densamente pubérulo; endocarpo tomentoso, esbranquiçado, amarelado a ferrugíneo. Sementes 0,7-1,1 × 0,5-0,7 cm, oblongas, ovalada-oblongas,; arilo alvo a amarelado recobrindo até a região apical ou totalmente a semente.

Nomes populares: camboatá-amarelo, camboatá, camboatã, caxuá-branco, pau-de-pombo, tata-piririca.

Material selecionado: BRASIL. ESPÍRITO SANTO: Ibitirama, Pedra Roxa, Alojamento ICMBIO, beira do rio, 23.X.2012, fl., T.B. Flores et al. 1475 (CVRD, ESA). MINAS GERAIS: Alto Caparaó, encosta da Serra do Caparão, abaixo do Parque Nacional, 24.X.1989, fl. e fr., J.R. Pirani 2552 (ESA, SPF); Barroso, Mata do Baú, 28.IX.2002, fl., L.C.S. Assis 583 (CESJ, CTES, ESAL, MBM, RB, SP, SPF); Caraça, córrego próxima a Pinheiros, 14.XI.1980, fl., Tales 347 (BHCB, MBM); Lagoa Santa, 4.IX.1864, fl., E. Warming (C); Poços de Caldas, mata da Colina, 30.X.1981, fr., J.Y. Tamashiro 1649 (MBM, UEC); Santa Luzia, 22.XI.1893, fr., A.F.M. Glaziou 20238 (P); São Bartholomeu, 22.VIII.1884, fl., A.F.M. Glaziou 14576 (C, P); Serro, ca. $30 \mathrm{~km}$ of Serro on road (MG-02) to Diamantina, fr., 26.II.1968, H.S. Irwin 20930 (UB). RIO DE JANEIRO: Itatiaia, 23.X.1928, fl., C. Porto 1808 (RB); Nova Friburgo, 8.X.1880, fl., A.F.M. Glaziou 11827 (BR, C, P); Petrópolis, IX, fl., O.C. Góes 18 (RB); Teresópolis, Venda Nova, propriedade do Sr. Waldemar, 28.X.2004, C.H.R. Paula 677 (RB). SÃO PAULO: Caconde, 8.XI.1994, fr., L.S. Kinoshita 94 (SP, UEC); Cajuru, 29.XI.1985, fr., L. Bernacci 129 (ESA, SPF); Campinas, bosque dos Jequitibás, fl., L.A.F. Matthes 7794 (MBM, UEC); Matão, mata da Virgínia, no interior de estrada que cruza mata, 25.VIII.1995, fl., A. Rozza 99 (ESA, MBM).

Matayba juglandifolia ocorre no sudeste do Brasil (ES, MG, RJ e SP) em florestas estacionais semidecíduas, matas ciliares e nas bordas destas formações, aparecendo ocasionalmente também na transição entre as florestas e o cerrado ou apenas nos cerrados. A altitude das coletas varia entre 400-1200 metros. Foi encontrada com flores nos meses de setembro a novembro e com frutos nos meses de outubro e novembro a fevereiro.

Matayba juglandifolia é uma das espécies que, apesar de apresentar a rede de nervuras proeminente na face adaxial dos folíolos, foi categorizada por Radlkofer (1934) por contar com a reticulação mais laxa (bem como $M$. grandis e $M$. pallens). Contudo, pode ser diferenciada de $M$. grandis pela nervação broquidódroma e as nervuras secundárias proeminentes na face adaxial ( $v s$. nervação eucamptódroma e as nervuras secundárias impressas). Com relação a $M$. obovata, um táxon posteriormente incluído nessa seção, $M$. juglandifolia é delimitada pelos folíolos cartáceos e esverdeados e flores entre 7-10 mm compr. (ES, $\mathrm{MG}, \mathrm{RJ}, \mathrm{SP})$, contra folíolos coriáceos e verdeamarelados ou alaranjados e flores de 4-8 $\mathrm{mm}$ compr. em $M$. obovata (PR, RJ e SP).

1.10. Matayba leucodictya Radlk., in Martius, Fl. bras. 13(3): 628. 1900. Tipo: BRASIL. RIO DE JANEIRO. Alto Macaé. I.1891-1892. A.F.M. Glaziou 18955 (lectótipo R! [aqui designado]; isolectótipos $\mathrm{C}$ !, $\mathrm{K}$ !, $\mathrm{M}$ !, $\mathrm{P}$ !).

Árvore; ramo cilíndrico, pubérulo a esparsamente pubescente. Folhas dispersas por todo o ramo; pecíolo 2,3-4,7 cm compr., cilíndrico, pubérulo a esparsamente pubescente; raque $16-23 \mathrm{~cm}$ compr., cilíndrica, bicanaliculada, pubérula a esparsamente pubescente; folíolos 3-12, subsésseis ou peciólulos 0,4-1,3 cm compr., subcilíndricos a canaliculados, esparsamente pubescentes; lâmina 11,5 × 1,4-3,1 cm, elípticos a elíptico-oblongos, cartáceos, planos, ápice agudo, obtuso a arredondado, base atenuada, assimétrica; margem subrevoluta, inteira, as vezes ondulada; concolores, castanho-acinzentados, castanho, (sub)glabros em ambas as faces; nervação esbranquiçada, proeminente na face adaxial, reticulação fechada; nervura central proeminente na face adaxial, glabra a subglabra em ambas as faces; nervação secundária broquidódroma, 8-12 pares, levemente proeminentes a proeminentes na face adaxial, oblíquas, arqueadas; domácias presentes, urceoladas, às vezes salientes na face adaxial dos folíolos. Inflorescências axilares, mais curtas que as folhas; pedúnculo 7-10,3 cm compr., (sub)cilíndrico, pubérulo a esparsamente 
pubescente, raque $8-16,8 \mathrm{~cm}$ compr., subcilíndrica a achatada, pubérula a densamente pubescente. Flores 6-7 mm compr.; pedicelo 2-3 mm compr., articulado na região basal, densamente pubescente; sépalas ca. $1 \mathrm{~mm}$ compr., ovaladas, livres a partir da base, lobos ca.0,7 mm compr., ápice agudo a obtuso; pubescentes a tomentosas na face abaxial, subglabras a esparsamente pubescentes na face adaxial, margem ciliada; pétalas ca. $1 \mathrm{~mm}$ compr., obovadas (largamente), ápice emarginado a arredondado, irregular a erodido, subglabras na face abaxial, tomentosa na face adaxial; base unguiculada, apêndice petalífero basal maior que a pétala, viloso; disco nectarífero glabro; fl. masc.: estames 3-4 mm compr., filetes iguais, geralmente sinuosos, raramente retos, densamente pubescentes nas regiões basal e central e pubescentes na apical, anteras glabras, pistilódio ca. $1 \mathrm{~mm}$ compr., densamente tomentoso; fl. fem.: estaminódios desconhecidos; gineceu ca.4 mm compr., globoso, levemente lobado, densamente pubescente, estilete ca. $1 \mathrm{~mm}$ compr., estigma trífido, (esparsamente) pubescentes (densamente). Cápsulas e sementes desconhecidas.

Material examinado: BRASIL. RIO DE JANEIRO: Petrópolis, fl., A.F.M. Glaziou 13621 (B, C, K, P).

Matayba leucodictya é encontrada em florestas úmidas do Rio de Janeiro e com flores em janeiro. A espécie mais próxima a M. leucodyctia é M. elaeagnoides por apresentar a raque dos folíolos bicanaliculada, nervação proeminente na face adaxial dos folíolos e a reticulação fechada, além da presença de domácias urceoladas. Porém, $M$. leucodyctia apresenta entre 8-18 pares de nervuras secundárias geralmente retilíneas, a nervação esbranquiçada e nervura central proeminente contrastando com a nervação amarelada ou avermelhada, nervura central impressa e nervuras secundárias geralmente arqueadas em número de 4-12 em M. elaeagnoides. Foram analisados apenas os sintipos para a espécie e desta maneira, fica evidente que novos esforços de coleta na área de ocorrência dessa espécie são necessários.

1.11. Matayba livescens (Radlk.) R.L.G. Coelho, V.C. Souza \& Ferrucci, Rodriguésia 65(3): 711715. 2014; Matayba guianensis f. livescens Radlk., Sitzungsber. Math.-Phys. Cl. Königl. Bayer. Akad. Wiss. München 4: 633. 1879. Tipo: BRASIL. BAHIA. s/d, Blanchet 3860 (lectótipo BR! [aqui designado]).

Matayba guianensis f. livescens subf. macrosperma Sitzungsber. Math.-Phys. Cl. Königl. Bayer. Akad.
Wiss. München 4: 633. 1879. Tipo: BRASIL. BAHIA. s/d, H. Wawra \& F. Maly 126 (lectótipo $\mathrm{W}$ ! [aquí designado]).

Árvores a arbustos, 2-8 m alt.; ramos cilíndricos a achatados, lenticelados, subglabros a pubérulos. Folhas dispersas por todo o ramo; pecíolo 2,6-4,5 cm compr., (sub)cilíndrico, subglabro a pubérulo; raque 1,7-10,9 $\mathrm{cm}$ compr., cilíndrica a bicanaliculada, subglabra a esparsamente pubescente; folíolos 4-10, subsésseis ou peciólulos $0,4-1 \mathrm{~cm}$ compr., subcilíndricos a canaliculados, pubérulos; lâmina 3,8-14,6 $\times$ 1,4-6,2 cm, elípticos, largamente elípticos, elíptico-oblongos, elíptico-ovados a ovalados, coriáceos, conduplicados, recurvados, ápice agudo, base aguda, atenuada ou raramente obtusa, assimétrica; margem revoluta, inteira; discolores, castanho-acinzentados a castanhoclaros,, subglabros a esparsamente pubescentes na face abaxial, verde-acinzentados a verdeescuros, brilhantes, subglabros a esparsamente pubescentes na face adaxial; nervação verdeacinzentada, verde-amarelada, castanho-amarelada a castanha, inconspícua a plana na face adaxial, reticulação aberta; nervura central proeminente a plana na face adaxial, subglabra a esparsamente pubescente em ambas as faces; nervação secundária broquidódroma, 6-12 pares, levemente proeminentes na face abaxial, oblíquas, geralmente retilíneas a raramente levemente arqueadas; domácias ausentes. Inflorescências axilares, mais compridas que as folhas, pedúnculo 4,5-17,1 cm compr., cilíndrico, pubérulo a densamente pubescente, raque $6-21,5 \mathrm{~cm}$, cilíndrica a achatada, pubérula a densamente pubescente. Flores 6-8 mm compr.; pedicelo 2-3 mm compr., articulado na região basal, pubescente (densamente); sépalas ca. $1,5 \mathrm{~mm}$ compr., ovaladas a obovadas, livres a partir da região mediana, lobos ca.0,7 mm compr., ápice obtuso a arredondado; pubérulas a pubescentes na face abaxial, pubescente na face adaxial, emaranhados; margem ciliada; pétalas 1-1,5 mm compr., largamente espatuladas a largamente obovadas, ápice arredondado, irregular a truncado, subglabras na face abaxial, lanosas na face adaxial; base unguiculada, apêndice petalífero basal menor, igual ou maior que a pétala, lanoso; disco nectarífero glabro; fl. masc.: estames 3-4 $\mathrm{mm}$ compr., filetes geralmente iguais, raramente diferentes, retos, densamente pubescentes até a região central, glabros a pubescentes na apical, anteras glabras a raramente subglabras, oblongas a oblongo-obovadas, pistilódio ca. $1 \mathrm{~mm}$ compr., 
densamente pubescente; fl. fem.: estaminódios ca. $2 \mathrm{~mm}$ compr.; gineceu 4-5 mm compr., ovário ovalado, levemente lobado, densamente pubescente; estilete 1-2 mm compr., estigma bífido ou trífido; esparsamente pubescente, Cápsulas 0,9$1,9 \times 0,5-2 \mathrm{~cm}$, subglobosas, fortemente lobadas, estípite ca. $2 \mathrm{~mm}$ compr., apiculadas, bicarpelares a tricarpelares, geralmente (1-2) 3 seminadas; epicarpo coriáceo, verrucoso a tuberculado, subglabro a densamente pubérulo; endocarpo tomentoso, esbranquiçado. Sementes 1-1,4 × 0,9$1,1 \mathrm{~cm}$, elipsoides a obovóides; arilo esbranquiçado recobrindo a região basal da semente.

Material selecionado: BRASIL. BAHIA: Ponço d'Areia, 1844, fl., J.S. Blanchet 3860 (G). ESPÍRITO SANTO: Vila Velha, Rodovia do Sol, ca. 22 km após Guarapari, Lagoa de Interlagos, loteamento Interlagos, 5.III.2001, fl., P. Fiaschi 653 (SP, SPF). RIO DE JANEIRO: Araruama, restinga da Praia Seca, Cômoros da Lagoa Pitanguinha, 20.XII.1982, fl. e fr., G.V. Somner 303 (GUA); Cabo Frio, Reserva Ecológica Estadual de Massambaba, próximo a Lagoa Salgada, 26.X.1993, fl. e fr., G.V. Somner 484 (RB); Casimiro de Abreu, restinga entre Barão de São João e Rio das Ostras, restinga da Praia Virgem, 31.I.1999, fl. e fr., R.N. Damasceno 723 (RB); Macaé, Lagomar, 9.V.1995, fr., D.S.D. Araújo 10254 (GUA); Rio das Ostras, Reserva Biológica União, baixada, 20.X.1997, fl. e fr., P.P. de Oliveira 313 (BHCB); Rio de Janeiro, Mendanha, Realengo, 29.IV.1880, fl., A.F.M. Glaziou 11823 (BR, C, P, S); Rio de Janeiro, Serra de Jacarepaguá, Morro da Tijuca, 8.VIII.1873, fl., A.F.M. Glaziou 6709 (C, P); Saquarema, Jacomé, próximo ao sambaqui do Jacoré, fr., 29.III.2000, C. Farney 3997 (RB).

Essa espécie é encontrada nos estados do noredeste (BA) e sudeste (ES e RJ), nas florestas de restinga, dunas semi-fixas ou em áreas periodicamente alagadas. Coletada com flores de dezembro a junho e com frutos em setembro, novembro a abril e junho.

Previamente categorizada como uma forma de $M$. guianensis (M. guianensis f. livescens) por Radlkofer (1879), M. livescens foi elevada ao nível de espécie por Coelho et al. (2014). Nesse trabalho, o lectótipo designado para o nome $M$. livescens foi o material H. Wawra \& F. Maly 126. Porém, posteriormente notamos que esse material é o único material citado na publicação do nome Matayba guianensis f. livescens subf. macrosperma e dessa maneira não poderia ser designado como lectótipo para o nome $M$. livescens e portanto, agora foi designado um novo lectótipo para essa espécie (J.S. Blanchet 3860).

As semelhanças entre essas espécies (M. livescens e M. guianensis) são os folíolos conduplicados e recurvados, nervação inconspícua na face adaxial dos folíolos e epicarpo dos frutos com superfície geralmente tuberculada. Porém, M. livescens diferencia-se de $M$. guianensis pelos folíolos coriáceos, discolores na maioria das vezes, com a face adaxial brilhante, nervuras secundárias geralmente arqueadas (apesar de parecerem curvadas, devido aos folíolos serem conduplicados e recurvados) e sem domácias (vs. folíolos cartáceos, concolores, com nervuras secundárias curvadas e a presença de domácias foveoladas ou urceoladas em $M$. guianensis). Aliás, $M$. livescens ocorre apenas nas florestas de restinga estando sempre relacionada a áreas sob a influência do oceano, enquanto $M$. guianensis é encontrada predominantemente nos cerrados, na floresta amazônica e às vezes em florestas estacionais.

1.12. Matayba marginata Radlk., Sitzungsber. Math.-Phys. Cl. Königl. Bayer. Akad. Wiss. München 9: 634.1879. Tipo: BRASIL. MINAS GERAIS. Serra da Piedade. P. Claussen 291 (lectótipo P! [aqui designado]; isolectótipos BR!, FI!, G!).

Matayba marginata f. elongata Radlk. Sitzungsber. Math.-Phys. Cl. Königl. Bayer. Akad. Wiss. München 9: 634.1879. Tipo: BRASIL. RIO DE JANEIRO. Nova Friburgo, Respiro. 4.XI.1881. $A$. F. M. Glaziou 13413 (neótipo P! [aqui designado]; isoneótipos BR!, F!, NY!).

Árvores a subarbustos, 0,5-10 m alt.; ramos cilíndricos, subglabros a pubescentes. Folhas congestas no ápice dos ramos, pecíolo 0,8-2,4 cm compr., subcilíndrico, subglabro a pubescente; raque 3,9-10 cm compr., geralmente subalada, raramente marginada, subglabra a pubescente; folíolos 10-22, sésseis; lâmina $1,1-5,6 \times 0,6-2,4 \mathrm{~cm}$, elípticos, elípticos-oblongos, largamente elípticos ou obovados, cartáceos, planos, ápice agudo, obtuso ou retuso, base atenuada, assimétrica, margem revoluta a fortemente revoluta, inteira; concolores, castanho ou esverdeado, subglabros a esparsamente pubescentes na face abaxial, castanho-claros a verde-escuros, brilhantes, (sub)glabros na face adaxial; nervação castanho a castanho-esverdeada, inconspícuos na face adaxial, reticulação aberta; nervura central proeminente na face adaxial, (sub) glabras na face adaxial, subglabra a esparsamente pubescente na face abaxial; nervação secundária broquidódroma, 4-8 pares, proeminentes a planas na face adaxial, oblíquas, retilíneas a arqueadas; domácias geralmente presentes, foveoladas, com ou sem tricomas na abertura, geralmente salientes na 
face adaxial dos folíolos. Inflorescências axilares, mais curtas que as folhas; pedúnculo 1,1-3,1 cm compr., achatado, (esparsamente) pubescente, raque 1,5-2,5 cm compr., achatada, (esparsamente) pubescente. Flores 6-8 mm compr.; pedicelo 1-3 mm compr., articulado na região basal, subglabro; sépalas 1,5 mm compr., ovaladas, livres a partir da base, lobos ca.0,7 mm compr., ápice agudo; (sub) glabras na face abaxial e na face adaxial; pétalas 1-1,5 mm compr., obovadas, largamente obovadas a obtruladas, ápice agudo a truncado, erodido, (sub)glabras em ambas as faces; base unguiculada, apêndice petalífero basal de mesmo tamanho ou maior que a pétala, viloso; disco nectarífero glabro; fl. masc.: estames 3-4 mm compr., filetes iguais, retos a levemente sinuosos, pubescentes até a região apical, anteras glabras, pistilódio ca. $1 \mathrm{~mm}$, densamente pubescente; fl. fem.: estaminódios 1-2 mm compr.; gineceu ca. $3 \mathrm{~mm}$ compr., ovário ovóide a ovóide-oblongo, globoso, levemente lobado, densamente pubescente; estilete ca. $1 \mathrm{~mm}$ compr., estigma bífido ou trífido; esparsamente pubescente. Cápsulas 0,5-1,4 × 0,4-1,6 cm, ovóides, globosas, levemente lobadas, estípite 1-2 mm, apiculadas; bicarpelares ou tricarpelares, 2-3 seminadas, epicarpo coriáceo, verrucoso, (sub) glabro; endocarpo tomentoso, esbranquiçado, amarelado a ferrugíneo. Sementes 0,8-1 × 0,5-0,7 $\mathrm{cm}$, oblongas; arilo alvo a amarelado recobrindo as regiões central, apical ou totalmente a semente. Material selecionado: BRASIL. BAHIA: Boa Nova, Parque Nacional de Noa Nova, Setor Azul, Fazenda Liberdade, região da Farofa, 1.III.2013, fr., L.Y.S. Aona 2058 et al. (HURB, RB). MINAS GERAIS: fl., $P$. Claussen 1528 (P); 1832, fl., C.F.P. Martius 925 (M, W); fl., G. Schüch (W); fl., F. Sellow 1113 (B, M, US); fl., F. Sellow B1901 c1389 (B); fl., Fra Custodio 217 (P); Catas Altas, serra do Caraça, 15.XII.2000, fl., R.C. Mota 1114 (BHCB, SPF); Diamantina, near Sopa on road São João da Chapada, $5 \mathrm{~km} \mathrm{NW}$ of junction with road from Curvelo to Diamantina, 23.XI.1985, fr., $W$. Thomas 4852 (K, SPF); Grão-Mogol, ca. 5-15 km ao norte da cidade, 16.X.1988, fl. e fr., R.M. Harley 25140 (BHCB, CEPEC, CTES, F, K, SPF); Lima Duarte, Parque Estadual do Ibitipoca, 6.X.1987, fl., P.M. Andrade 1025 (BHCB, CTES); Ouro Preto, 5.X.1984 fl., A.A. Magalhães Gomes 1295 (M); Ouro Preto, Cachoeira, 11.XI.1984, fl., A.A. Magalhães Gomes 2033 (M); Ouro Preto, Serra de Ouro Preto, X.1893, fl., C.A.W. Schwacke 9543 (M, P); Rio Preto, Serra do Funil, 3.X.1987, fl., F.R.G. Salimena 21637 (CESJ, ESA); Santa Rita do Jacutinga, 31.VII.1970, fr., P.L. Krieger 8894 (BHCB, CESJ, ESA, MBM, RB, SPF). PARANÁ: Tunas do Paraná, Pacas, 4.X.1999, fl., J.M. Silva 3083 (CTES, HUEFS, MBM). RIO DE JANEIRO: Nova Friburgo,
4.XI.1881, fr., A.F.M. Glaziou 13413 (R). SÃO PAULO: Cotia, IX.1929, fl., P. Gonçalves (SPF 106884).

Distribuída no Brasil nas regiões nordeste (BA), sudeste (MG, RJ, SP) e sul (PR), geralmente nos cerrados e campos rupestres com afloramentos rochosos, em carrascos com solo arenoso, matas de galeria e florestas úmidas. Em Minas Gerais, mais especificamente no município de Ouro Preto, essa espécie foi encontrada em vegetação denominada de canga sobre um solo com alta concentração de ferro, determinando o porte arbustivo da planta que se prende superficialmente ao solo. Contraposto a isso, no Paraná, existem árvores de até 10 metros de altura encontradas no interior de florestas úmidas (J.M. Silva 3083). Matayba marginata foi coletada em altitudes variando entre 155 e 1450 metros, porém a faixa predominante é acima dos 1000 metros. Foi encontrada com flores de setembro a abril e com frutos nos meses de maio a dezembro e em fevereiro.

Matayba marginata é facilmente reconhecida geralmente pela presença de domácias (como em M. guianensis, $M$. juglandifolia e $M$. punctata, como exemplos), número (10-22) e tamanho dos folíolos, além da raque das folhas subalada a marginada. Apesar de $M$. heterophylla também apresentar a raque alada e domácias, essa espécie tem folíolos com margem serreada ou serrulada e as domácias salientes na face adaxial.

Radlkofer (1934) propôs duas formas (M. marginata f. marginata e $M$. marginata $\mathrm{f}$. elongata) para essa espécie, separadas pelas alas da raque foliar (subalada na forma marginata e submarginada na forma elongata) e pelo tamanho dos folíolos (2-3 cm compr. na forma marginata e 4-5 cm compr. na forma elongata). Contudo, essas formas não são aceitas no presente trabalho, visto que as variações morfológicas descritas por Radlkofer (1934) são contínuas entre os espécimes analisados.

1.13. Matayba mollis Radlk., Sitzungsber. Math.Phys. Cl. Königl. Bayer. Akad. Wiss. München 9: 634. 1879. Tipo: BRASIL. MINAS GERAIS. F. Sellow B2069 c2021 (lectótipo B! [aqui designado]; isolectótipos M!, US!).

Fig. 6

Árvores a subarbustos, 2-6 m alt.; ramos cilíndricos, pubérulos a pubescentes. Folhas dispersas por todo o ramo, pecíolo $1,1-5,8 \mathrm{~cm}$ compr., (sub)cilíndrico, pubescente; raque 3,813,9(-22,6) cm compr., subcilíndrica, pubescente; folíolos 4-14, sésseis ou peciólulos ca.0,5 cm compr., subcilíndricos a canaliculados, densamente 


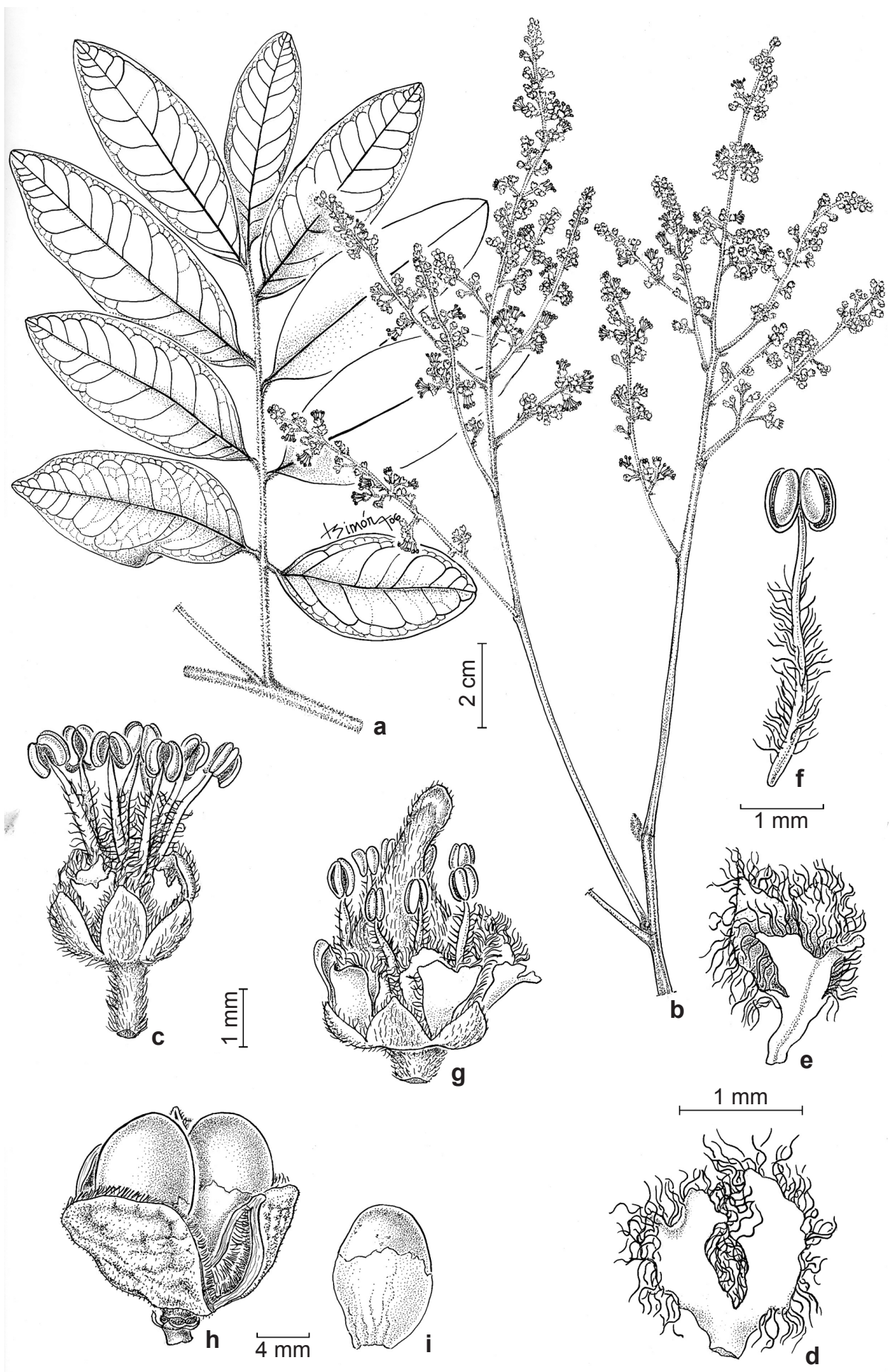

Figura 6 - Matayba mollis Radlk. - a. ramo; b. inflorescência; c. flor estaminada; d. pétala, face adaxial, evidente o apêndice petalífero; e. pétala, face externa; f. estame da flor estaminada; g. flor pistilada; h. fruto; i. semente. [a,g. Stehmann 20788 (CTES); b-f. Hatschbach et al. 67318 (CTES); h,i. Pirani CFCS 6874 (CTES)].

Figure 6 - Matayba mollis Radlk. - a. branch; b. inflorescence; c. staminate flower; d. petal, inner face, showing petaliferous appendix; e. petal, outer face; f. stamen in staminate flower; g. pistillate flower; h. fruit; i. seed. [a,g. Stehmann 20788 (CTES); b-f. Hatschbach $e t$ al. 67318 (CTES); h,i. Pirani CFCS 6874 (CTES)]. 
pubescentes; lâmina $(2,2-) 3-14,1 \times 1,3-3,4$ $\mathrm{cm}$, elípticos, elíptico-lanceolados, ovados ou oblongos, cartáceos, geralmente conduplicados, raramente recurvados, ápice agudo a obtuso, raramente arredondado ou emarginado, base obtusa a acuminada, assimétrica, margem subrevoluta a revoluta, inteira; concolores, castanhos, pubescentes (densamente), raramente esparsamente pubescentes na face abaxial, castanho-claros a castanho-escuros, subglabros a esparsamente pubescentes na face adaxial; nervação amarelada a avermelhada, inconspícua na face adaxial, reticulação aberta; nervura central levemente proeminente na face adaxial, pubescente em ambas as faces; nervação secundária broquidódroma, 8-12 pares, planas a impressas na face adaxial, oblíquas, retilíneas a levemente arqueadas; domácias ausentes. Inflorescências axilares ou terminais, menos ou mais compridas que as folhas; pedúnculo 2,4-16,3 cm compr., subcilíndrico a achatado, pubescente (densamente); raque 8,4-12,6 cm compr., achatada, pubescente (densamente). Flores 6-9 mm compr.; pedicelo 2-3 mm compr., articulado na região central ou apical, pubescente; sépalas 1-1,5 mm compr., ovaladas, livres a partir da base, lobos $0,7-1 \mathrm{~mm}$ compr. ápice agudo a obtuso; pubescentes em ambas as faces, margem ciliada; pétalas 1-2,5 mm compr., obovadas, ápice truncado a emarginado, glabras na face abaxial, subglabras a vilosas na face adaxial, geralmente com margem ciliada; base unguiculada, apêndice petalífero basal do mesmo tamanho ou maior que a pétala, viloso; disco nectarífero glabro; flores masc.; estames 2-4 mm compr., filetes iguais ou diferentes, retos, pubescentes (densamente) pubescentes na região central ou apical, anteras glabras, pistilódio ca. $1 \mathrm{~mm}$, tomentoso; flores fem.; estaminódios 1-1,5 mm compr.; gineceu ca.2,5 mm compr., ovário obovóide, levemente lobado, estilete ca. $0,5 \mathrm{~mm}$ compr., estigma capitado, tomentosos.. Cápsulas 1-2,3 × 1-1,7 cm, elipsoides a obovóides, levemente lobadas, estípite ca. $2 \mathrm{~mm}$ compr., apiculadas, bicarpelares a tricarpelares, 1-2-3 seminadas; epicarpo coriáceo, verrucoso, pubescente e ferrugíneo; endocarpo viloso, esbranquiçado a ferrugíneo. Sementes $1-1,2 \times$ $0,7-0,9 \mathrm{~cm}$, oblongas; arilo amarelado recobrindo as regiões basal e central da semente.

Nomes populares: mataíba.

Material selecionado: BRASIL. MINAS GERAIS: fl., P. Claussen 327 (K); F. Sellow 1217 (B, M); 1858, H.A. Wedell 1536 (G, M, P); 1858, H.A. Wedell 1684 (G, P); fl., F. Sellow 368 (B); Barão dos Cocais, estrada para Caeté, 19.XII.1982, fl., J.R. Pirani 377 (CTES, SP, SPF);
Belo Horizonte, Serra do Caraça, ca. $70 \mathrm{~km}$ a sudeste de Belo Horizonte, 17.XI.1077, fl., R. Monteiro 6387 (BHCB, RB, UEC); Cachoeira do Campo, 13.XII.1893, fl., A.F.M. Glaziou 20235 \& C.A.W. Schwacke 10034 (C, P); Cachoeira do Campo, 23.X.1893, fl., A.F.M. Glaziou 28235 (R); Capelinha, 9.XI.1981, bt., O.A. Salgado 206 (RB); Catas Altas, Serra do Caraça, 14.XII.2000, fl., R.C. Mota 1039 (BHCB, CESJ); Datas, estrada CurveloDiamantina, Km 108, em estrada vicinal, 24.XI.1985, fl., J.R. Pirani CFCR2715 (K, SPF); Diamantina, on road to Medanha, 26.I.1969, fr., H.S. Irwin 22636 (R, UB); Divinópolis, bairro Belvedere, 17.VI.1989, fl., F.M. de Oliveira 208 (ESAL); Itabirito, 19.XII.1970, fl., P.L. Krieger 9723 (BHCB, CESJ, ESA); Joaquim Felício, Serra do Cabral, próximo a matinha, 18.XI.1997, fl., $G$. Hatschbach 67217 (CTES, ESA, FLOR, HUEFS, MBM); Santana do Riacho, Km106 ao longo da Rodovia Belo Horizonte - Conceição do Mato Dentro, 9.XI.1982, fl., J.R. Pirani 6752 (CTES, SP, SPF); Turmalina, Peixe Cru, 3.XII.1991, bt., fl., M.G. Carvalho 850 (BHCB).

Matayba mollis é endêmica de Minas Gerais e ocorre principalmente nos cerrados e campos rupestres com afloramentos rochosos, além de matas ciliares e semidecíduas, em altitudes que variam entre 672 e 1350 metros. Floresce nos meses de junho, agosto e de outubro a janeiro e frutifica entre dezembro e fevereiro.

As únicas espécies da seção Matayba com a face abaxial dos folíolos, ramos e folhas pubescentes (densamente), são M. mollis e M. punctata, que, além disso, são endêmicas de Minas Gerais. Matayba mollis tem folíolos elíptico-lanceolados, elípticos, oblongos a subovalados, com 8-12 pares de nervuras secundárias e falta de domácias, enquanto M. punctata tem folíolos suborbiculares, com 3-6 pares de nervuras secundárias e uma ou mais domácias.

Vale ressaltar que, raramente, alguns materiais desta espécie apresentam a face abaxial dos folíolos esparsamente pubescente e mesmo assim, as características da nervação (inconspícua na face adaxial, reticulação aberta, nervura central e nervuras secundárias planas a impressas na face adaxial, retilíneas a levemente arqueadas) e a falta de domácias, ainda são suficientes para a identificação.

1.14. Matayba obovata R.L.G. Coelho, V.C. Souza \& Ferrucci, Brittonia 64(1): 2012. Tipo: BRASIL. PARANÁ. Bocaiúva do Sul, rodovia para o Parque das Lauráceas, rio Capivari. 1.IX.1994. J.M. Silva \& C.B. Poliquesi 1397 (holótipo MBM!; isótipos HUEFS!, RB!, UB!).

Árvores a arvoretas, (2-)7-16(-30) m alt.; ramos cilíndricos a achatados, glabros a subglabros. 
Folhas dispersas por todo o ramo, pecíolo 2,4-7,3 cm compr., (sub)cilíndrico, glabro a subglabro; raque 2,7-18,5 cm compr., subcilíndrica, (sub) glabra; folíolos 2-8, subsésseis; lâmina 6,1-19,9 × $1,9-8,3 \mathrm{~cm}$, geralmente obovados, oblanceolados, estreitamente obovados ou raramente espatulados, coriáceos, planos, ápice agudo a obtuso, raramente retuso, base clavada a atenuada, assimétrica, margem revoluta, inteira; concolores, amarelados a alaranjados, brilhantes, (sub)glabros em ambas as faces; nervação amarelada, proeminente na face adaxial, reticulação fechada; nervura central plana a proeminente na face adaxial, glabra em ambas as faces; nervação secundária broquidódroma, 6-12 pares, proeminentes na face adaxial, oblíquas, retilíneas; domácias geralmente ausentes, raramente presentes, urceoladas, não salientes na face superior dos folíolos. Inflorescências axilares, menos ou mais compridas que as folhas; pedúnculo 1,1-6,3 cm compr., cilíndrico, glabro a esparsamente pubescente, raque $1,7-8,6(-23)$ $\mathrm{cm}$ compr., cilíndrica a achatada, subglabra a pubescente. Flores 4-8 mm compr.; pedicelo 1-3 mm compr., articulado nas regiões basal, central ou apical, pubescente; sépalas 1,5-2 $\mathrm{mm}$ compr., livres a apartir da região mediana, ovaladas (largamente), lobos $0,7-1 \mathrm{~mm}$ compr., ápice geralmente arredondado a obtuso, raramente agudo; esparsamente pubérulas na face abaxial, subglabras na face adaxial; pétalas $1-2 \mathrm{~mm}$ compr., obovadas a ovaladas, ápice emarginado a arredondado ou erodido, glabras a subglabras na face abaxial, lanosas na face adaxial, margem ciliada; base unguiculada, apêndice petalífero basal de mesmo tamanho ou maior que a pétala, viloso; disco nectarífero glabro; fl. masc.: estames 2-5 mm compr., filetes iguais, geralmente retos, raramente sinuosos, densamente pubescentes na região basal ou até a região central, (sub)glabros na região apical, anteras glabras, pistilódio ca.1 $\mathrm{mm}$, densamente pubescente; fl. fem.: estaminódios 1,5-2 mm compr.; gineceu de ca.4 mm compr., ovário, ovalado-oblongo, levemente lobado, densamente pubescente, estilete ca. $2 \mathrm{~mm}$ compr., estigma trífido, densamente pubescente. Cápsulas $1,1 \times 0,7-1,3 \mathrm{~cm}$, ovóides, subglobosas, lobadas, estípite ca. $2 \mathrm{~mm}$ compr., apiculadas; tricarpelares, 3 seminadas, epicarpo coriáceo, subverrucoso, (sub)glabro; endocarpo tomentoso. Sementes desconhecidas.

Material selecionado: BRASIL. PARANÁ: Antonina, Sapimanduva, 25.X.1972, fl., G. Hatschbach 30548 (MBM); Bocaiúva do Sul, rodovia para o Parque das
Lauráceas, rio Capivari, 1.IX.1994, fl., J.M. Silva 1397 (MBM, RB, UB); Guaraqueçaba, Serrinha, 13.IX.1967, fl., G. Hastchbach 17187 (MBM); Guaratuba, rio Imbira, 15.VII.1971, fl., G. Hatschbach 26855 (MBM); Morretes, Engenheiro Lange, I.1974, fr., G. Hatschbach 15322 (MBM, P); Paranaguá, Tabuleiro do Guarani, 2.XI.1965, fl., G. Hatschbach 13082 (MBM). RIO DE JANEIRO: Miguel Pereira, REBIO Tinguá, estrada do Ouro, proximidades do rio São Pedro, 13.XI.2001, fr., S.J. Silva Neto 1504 (RB); Serra da Estrela, fl., A.F.M. Glaziou 6492 (C, P). SÃO PAULO: Cananéia, estrada Cananéia - Pariquera-Açu, ca. $19 \mathrm{~km}$ de Cananéia, 6.IX.1994, fl., V.F. Ferreira 37 (CTES, SP); Iguape, Estação Ecológica de Juréia-Itatins, 27.VIII.1983, fl., J.R. Pirani 817 (SPF); Iguape, Estação Ecológica Juréia-Itatins, Serra da Juréia, trilha do Imperador, em direção a praia do Rio Verde, 12.XII.1992, fr., E.A. Anunciação 137 (SP, SPSF); Pariquera-Açu, Estação Experimental do Instituto Agronômico, 23.VIII.1995, fl., N.M. Ivanauskas 291 (ESA); Ribeirão Branco, Parque Estadual de Carlos Botelho, Km 55, ca. 23 km do núcleo do Parque, 3.IX.1987, fl., A. Gentry 58893 (SPF, SPSF); São Miguel Arcanjo, Parque Estadual Carlos Botelho, 09.IX.1992, bt., fl., P.L. de Moraes 706 (CTES, ESA).

Matayba obovata é encontrada no RJ, SP e PR, em florestas ombrófilas densas e entre as florestas ombrófilas e as florestas de restinga em altitudes que variam entre 10 e 800 metros. Foi encontrada com flores nos meses de março, junho, agosto a outubro e com frutos nos meses de setembro a dezembro.

Essa espécie é semelhante a $M$. juglandifolia por apresentar os folíolos com nervação fechada e proeminente na face adaxial, podendo ser diferenciadas pelos folíolos coriáceos, verdeamarelados ou alaranjados e geralmente obovados, as nervuras secundárias em número de 6-12 pares, retilíneas e oblíquas em relação à nervura central em $M$. obovata, enquanto em $M$. juglandifolia, os folíolos apesar de serem também subcoriáceos, na maioria das vezes são cartáceos, esverdeados, com nervuras secundárias de 6-18 pares e geralmente arqueadas. Além disso, as flores de $M$. obovata variam entre 4-8 $\mathrm{mm}$ compr., tem o estilete com aproximadamente $2 \mathrm{~mm}$ compr., e epicarpo dos frutos (sub)glabro enquanto as flores têm 7-10 mm compr., estilete 5-7 mm compr. e epicarpo pubescente com tricomas curtos e adpressos em M. juglandifolia.

1.15. Matayba punctata (Cambess.) Radlk., Sitzungsber. Math.-Phys. Cl. Königl. Bayer. Akad. Wiss. München 9: 634. 1879; Cupania punctata Cambess. in St. Hillaire Fl. bras. Mer. 1: 389. 1825. Tipo: BRASIL. MINAS GERAIS. Serra 
de Curumataí. 1816-1821. A. St-Hilaire 1988 (lectótipo P! [aqui designado]; isolectótipos G!, MPU!).

Fig. 7

Arbustos ou arvoretas, 1,4-1,8 m alt.; ramos cilíndricos, pubérulos a pubescentes. Folhas dispersas por todo o ramo, pecíolo 1-1,5 cm compr., (sub)cilíndrico, pubescentes (densamente); raque 2,9-6,2 cm compr., subcilíndrica a bicanaliculada, pubescente; folíolos 8-12, sésseis ou peciólulos 1-2 $\mathrm{mm}$ compr., densamente pubescentes, subcilíndricos; lâmina 1,9-4,7 × 0,6-1,6 cm, largamente elípticos a largamente obovados, cartáceos, planos, ápice obtuso a emarginado, base atenuada, levemente assimétrica, margem subrevoluta, inteira; concolores, castanho-escuro, (esparsamente) pubescentes na face abaxial, castanho-escuro, brilhantes, subglabros na face adaxial; nervação castanho, inconspícua na face adaxial, reticulação aberta; nervura central proeminente na face adaxial, (esparsamente) pubescente na face abaxial; nervação secundária broquidódroma, 3-6 pares, levemente proeminentes na face adaxial, oblíquas, retilíneas a arqueadas; domácias geralmente ausentes, presentes foveoladas, não salientes na face adaxial dos folíolos. Inflorescências axilares, mais curtas que as folhas; pedúnculo $0,7-4,1 \mathrm{~cm}$ compr., (sub)cilíndrico, pubescente (densamente), raque $0,4-4,3 \mathrm{~cm}$ compr., achatada, pubescente (densamente). Flores ca. $4 \mathrm{~mm}$ compr.; pedicelo ca. 1 mm compr., articulado na região basal, densamente pubescente; sépalas ca. $0,5 \mathrm{~mm}$ compr., ovaladas, livres a partir da região mediana, lobos ca. $0,3 \mathrm{~mm}$ compr., ápice agudo a obtuso; (esparsamente) pubescentes na face abaxial, subglabras na face adaxial, margem ciliada; pétalas menores que $1 \mathrm{~mm}$ compr., ovaladas, ápice levemente mucronado, subglabras em ambas as faces; base unguiculada, apêndice petalífero basal maior que as pétalas, lanoso; disco nectarífero glabro; fl. masc.: estames ca. $2 \mathrm{~mm}$ compr., filetes iguais, retos a levemente sinuosos, pubescentes até a região apical, anteras glabras, pistilódio ca. $0,5 \mathrm{~mm}$, densamente pubescente; fl. fem.: desconhecidas. Cápsulas 1-1,1 × 0,8-0,9 cm, ovóides, globosas, lobadas, estípite ca. $1 \mathrm{~mm}$, apiculadas; bicarpelares ou tricarpelares, 1-seminada, epicarpo coriáceo, verrucoso, subglabro; endocarpo tomentoso, amarelado a ferrugíneo. Sementes $0,8-1 \times 0,5-0,7$ $\mathrm{cm}$, oblongas; arilo alvo a amarelado recobrindo a metade ou totalmente a semente.

Material examinado: BRASIL. MINAS GERAIS: Datas, estrada Curvelo-Diamantina, Km 108, em estrada vicinal, 24.XI.1985, fr., R.M. Silva ESA107545 (ESA); Diamantina, estrada Diamantina-Medanha, 10.XII.1992, fr., H.F. Leitão Filho 27734 (UEC); Diamantina, estrada para Mendanha a $15 \mathrm{~km}$ de Diamantina, 31.X.1988, fr., R.M. Harley 25473 (ESA); Diamantina, Neco Motta, 4.XI.1937, fl., M. Barreto 9434 (R); Guinda Conselheiro da mata, 4.VI.1985, fr., H.F. Leitão Filho (UEC); Fanabo, inter Fanabo \& Estiva, fl., J.B.E. Pohl 3401 (W); Ouro Preto, serra de Ouro Preto, 18.X.1884, fr., A.F.M. Glaziou 14575 (BR, C, P, RB).

Essa espécie ocorre apenas no estado de Minas Gerais, nos campos rupestres, em altitudes maiores que 1000 metros e geralmente em solos com afloramentos rochosos, ocorrendo frequentemente próxima a cursos d'água. Foi coletada com flores em outubro e novembro e com frutos em novembro e dezembro.

Matayba punctata é diferenciada de $M$. mollis pelo formato dos folíolos (largamente obovados a largamente elípticos e ápice geralmente emarginado em $M$. punctata contra geralmente elíptico-lanceolados a subovalados e ápice agudo a obtuso em $M$. mollis) e pelas nervuras secundárias levemente proeminentes em número de 3-6 pares em $M$. punctata ( $v s$. nervuras secundárias planas a impressas em número de 8-12 pares em $M$. mollis). Já as flores de $M$. punctata têm aproximadamente $4 \mathrm{~mm}$ compr. e as sépalas são esparsamente pubescentes na face abaxial e subglabras na face adaxial (em M. mollis as flores têm de 6-9 mm compr., sépalas em ambas as faces com tricomas adpressos).

1.16. Matayba stenodictya Radlk., in Mart., Fl. bras. 13(3): 629. 1900. Tipo: BRASIL. MINAS GERAIS. Serra de Antônio Pereira. C.A.W. Schwacke 8746 (lectótipo M! [aqui designado]; isolectótipo F!).

Árvores ou arbustos, 1-6 m alt.; ramos cilíndricos, glabros a esparsamente pubescentes. Folhas dispersas por todo o ramo; pecíolo 1-4,5 cm compr., cilíndrico a canaliculado, glabro a pubescente; raque 3,6-16 cm compr., subcilíndrica, plana a bicanaliculada, (esparsamente) pubescente; folíolos 4-10, sésseis ou peciólulos $0,1-0,4 \mathrm{~cm}$ compr., canaliculados, (esparsamente) pubescentes (densamente); lâmina 1,2-12,9 × 0,6-3,7 cm, elípticos, largamente elípticos a lanceolados, cartáceos ou coriáceos geralmente conduplicados, geralmente recurvados, ápice agudo a acuminado, raramente emarginado, base atenuada, simétrica a levemente assimétrica, margem subrevoluta, inteira; discolores, castanho-claro na face abaxial, (sub)glabros na face abaxial, verde-acinzentado, 


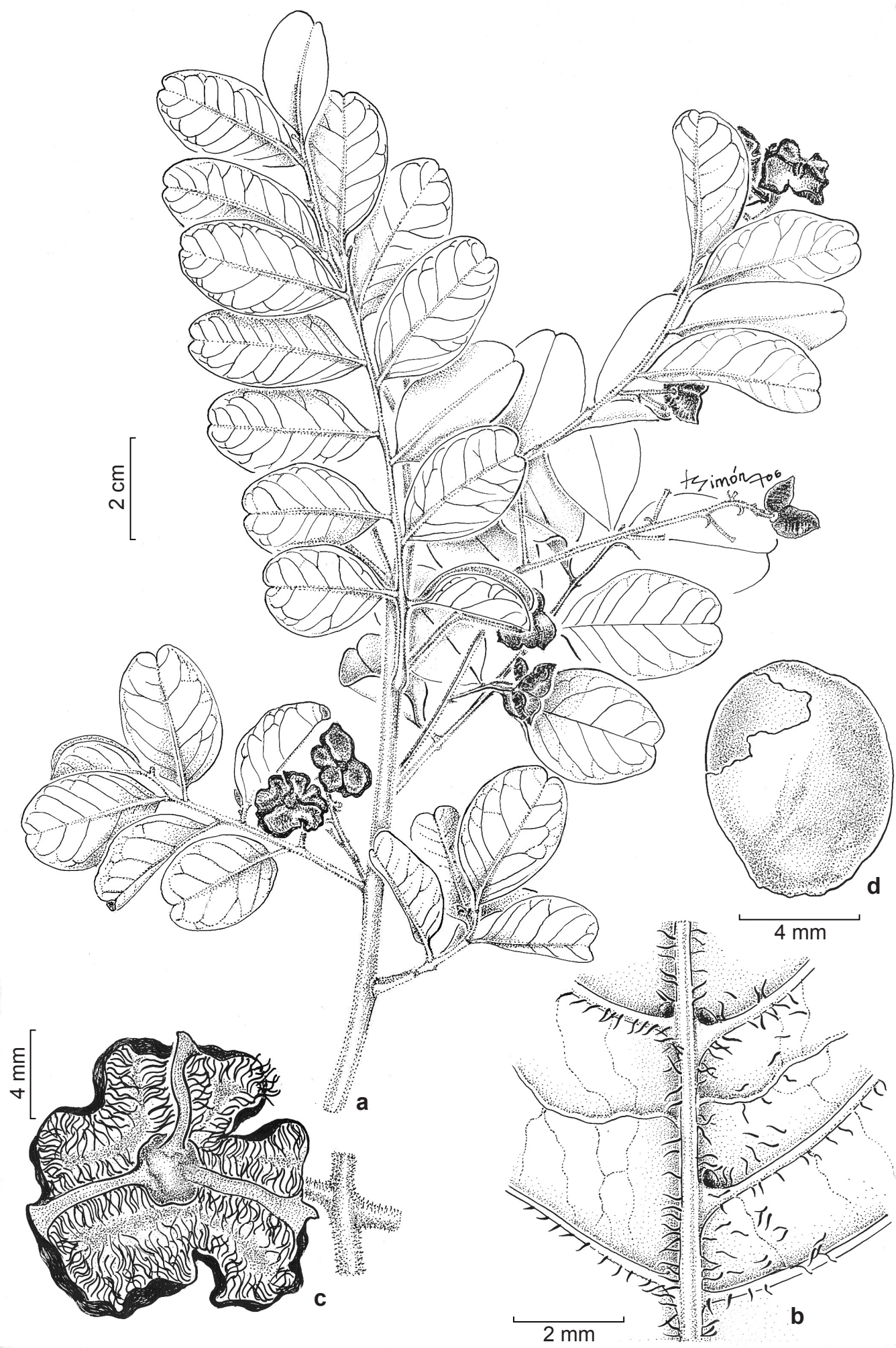

Figura 7 - Matayba punctata Radlk. - a. ramo com frutos; b. detalhe da face abaxial mostrando uma domacia foveolada; c. fruto aberto com endocarpo viloso; d. semente e arilo. [a-d. Arbo et al. 4457 (CTES)].

Figure 7 - Matayba punctata Radlk. - a. branch with fruits; b. detail of abaxial surface showing pit domatia; c. open fruit with villous endocarp; d. seed and aril. [a-d. Arbo et al. 4457 (CTES)]. 
acinzentado ou castanho-escuro, brilhantes, glabros na face adaxial; nervação esbranquiçada a amarelada, geralmente proeminente a raramente inconspícua na face adaxial, reticulação fechada; nervura central geralmente impressa a raramente plana, subglabra na face adaxial, glabra a pubescente com os tricomas nas laterais na face abaxial; nervação secundária broquidódroma, 6-14 pares, impressas a planas na face adaxial, geralmente perpendiculares, retilíneas; domácias ausentes. Inflorescências axilares, paniculiformes, menos ou mais compridas que as folhas; pedúnculo 0,5-7,5 cm compr., cilíndrico, subglabro a esparsamente pubescente, raque $1-20 \mathrm{~cm}$ compr., achatada, (esparsamente) pubescente. Flores 4-7 mm compr.; pedicelo 1-3 mm compr., articulado nas regiões basal ou central, (esparsamente) pubescente; sépalas 1-1,5 mm compr., largamente ovaladas, livres a partir das regiões basal ou mediana, lobos ca.0,7 mm compr., ápice agudo a obtuso; (esparsamente) pubescentes na face abaxial, pubescentes na face adaxial, margem ciliada; pétalas 1-2 mm compr., largamente ovaladas a suborbiculares, ápice arredondado, as vezes apiculado, (sub)glabras na face abaxial, vilosa na face adaxial, margem ciliada; base unguiculada, apêndice petalífero basal menor ou de mesmo tamanho que a pétala, viloso; disco nectarífero (sub)glabro; fl. masc.: estames 3-4 $\mathrm{mm}$ compr., filetes iguais, retos, pubescentes até a região central, (sub)glabros na região apical, anteras (sub)glabras; pistilódio ca. $1 \mathrm{~mm}$ compr., densamente pubescente; fl. fem.: estaminódios ca. $1 \mathrm{~mm}$ compr.; gineceu ca.1,5 mm compr., ovário ovóide, levemente lobado, (esparsamente) pubescente (densamente); estilete 1-2 mm compr., estigma capitado, esparsamente pubescente.. Cápsulas $0,8-1,2 \times 0,8-1,3 \mathrm{~cm}$, globosas, levemente lobadas, estípite ca. $1 \mathrm{~mm}$ compr., apiculadas; tricarpelares, 1-3 seminadas, epicarpo coriáceo, verrucoso, (esparsamente) pubescente; endocarpo viloso, amarelado. Sementes $0,4-0,5$ $\times 0,3-0,4 \mathrm{~cm}$, elipsoides a oblongas; arilo alvo recobrindo até a região central da semente.

Material examinado: BRASIL. MINAS GERAIS: Diamantina, estrada para Conselheiro da Mata, Km 189, fl., R. Mello-Silva et al. CFCR7915 (SPF); Lagoa Santa, fr., E. Warming (C); Serra do Cipó, Km 134, 25.X.1961, fr., A.P. Duarte 5691 (ESA, RB, SPFR); Santana do Riacho, ao longo da rodovia Belo Horizonte-Conceição do Mato Dentro, Km 126 (atual 115), 19.XII.1979, fr., J.R. Pirani \& M.C. Henrique CFSC5886 (SP, SPFR); Santana do Riacho, ao longo da rodovia Belo HorizonteConceição do Mato Dentro, Km 132, 29.II.1980, J.R.
Pirani CFSC5959 (SP, SPFR); Serra de Antônio Pereira. C.A.W. Schwacke 11278 (M).

Espécie endêmica de Minas Gerais encontrada na maioria das formações vegetacionais do estado, inclusive em matas ciliares e campos rupestres com solos arenoso ou pedregoso. Foi coletada com flores em agosto e setembro, e com frutos em outubro.

Matayba stenodictya pode ser reconhecida facilmente por apresentar os folíolos discolores, geralmente curvados e conduplicados, com nervuras secundárias retilíneas, geralmente impressas ou inconspícuas na face adaxial e sem domácias. Próximas morfologicamente, $M$. elaeagnoides e $M$. leucodictya por apresentar a nervação fechada, essas espécies apresentam folíolos concolores, não conduplicados ou recurvados e a presença de domácias. Vale ressaltar que apesar de Radlkofer (1934) posicionar essa espécie em um grupo que apresenta a nervação reticulada e proeminente na face adaxial dos folíolos, foi encontrado um material (Mello-Silva et al. CFCR7915) com a nervação inconspícua ou até plana, fazendo com que essa espécie, juntamente a $M$. heterophylla, sejam as únicas dentro da seção que apresentam variação no padrão de nervação.

1.17. Matayba sylvatica (Casar.) Radlk., Sitzungsber. Math.-Phys. Cl. Königl. Bayer. Akad. Wiss. München 9: 631. 1879; Cupania sylvatica Casar. Nov. Stirp. Bras. 46. 1842. Tipo: BRASIL. RIO DE JANEIRO. G. Casaretto 558 (lectótipo $\mathrm{G}$ ! [aqui designado]).

Nomes-populares: Camboatá-do-mato, camboatá-açú.

Árvores, 6-7 m alt.; ramos cilíndricos, glabros a esparsamente pubescentes. Folhas dispersas por todo o ramo, pecíolo 2,8-5,6 cm compr., (sub)cilíndrico, glabro a esparsamente pubescente; raque 2,1-12,4 cm compr., subcilíndrica a bicanaliculada, (sub)glabra; folíolos 6-10, peciólulos 0,5-0,9 cm compr., planos a canaliculados, glabro a esparsamente pubescente; lâmina 5,2-12,4 × 1,1-2,7 cm, elípticolanceolados, elíptico-oblongos a oblanceolados, cartáceos, planos, ápice agudo a levemente mucronado, base clavada a atenuada, assimétrica, margem subrevoluta, inteira; concolores, castanho a castanho-esverdeados, brilhantes, (sub)glabros na em ambas as faces; nervação castanho, inconspícua na face adaxial, reticulação aberta,; nervura central proeminente na face adaxial, subglabra em ambas as faces; nervação secundária broquidódroma, 
7-14 pares, levemente proeminentes a planas na face adaxial, oblíquas, retilíneas; domácias geralmente presentes, foveoladas, não salientes na face adaxial dos folíolos. Inflorescências axilares, menos ou mais compridas que as folhas; pedúnculo (sub)cilíndrico, 0,6-6,9 cm compr., subglabro a esparsamente pubescente, raque subcilíndrica a achatada, 18,4-29,8 cm compr., (esparsamente) pubescente. Flores 7-9 mm compr.; pedicelo 2-4 mm compr., articulado na região basal, subglabro a esparsamente pubescente; sépalas ca.1,5 mm compr., ovaladas a ovalado-triangulares, livres a partir da base, lobos ca. $1 \mathrm{~mm}$ compr., ápice agudo; pubérulas na face abaxial, densamente pubérulas na face adaxial, margem ciliada; pétalas ca. $2 \mathrm{~mm}$ compr., obovadas, ápice arredondado a truncado, erodido ou irregular, glabras na face abaxial, lanosas na face adaxial, margem ciliada; base unguiculada, apêndice petalífero basal menor que a pétala, viloso; disco nectarífero glabro; fl. masc.: desconhecidas; fl. fem.: estaminódios ca.1 $\mathrm{mm}$ compr.; gineceu de ca. $4 \mathrm{~mm}$ compr., ovário ovalado-globoso a ovalado-elipsoide, levemente lobado, estilete ca. $2 \mathrm{~mm}$ compr., estigma trífido, pubescente. Cápsulas 1,3-1,7 × 1-1,7 cm, globosas a subglobosas, lobadas, estípite ca. $1 \mathrm{~mm}$ compr., apiculadas; bicarpelares a tricarpelares, 1-2 seminadas, epicarpo subcoriáceo, subverrucoso a verrucoso, às vezes tuberculado, estrigiloso; endocarpo viloso, esbranquiçado a amarelado. Sementes $0,8-1,4 \times 0,6-0,9 \mathrm{~cm}$, oblongas a obovóide-oblongas; arilo recobrindo a região central da semente.

Material examinado: BRASIL. ESPÍRITO SANTO: Santa Teresa, Estação Biológica de Santa Lúcia, ao lado esquerdo rio Timbuí, 6.VII.1989, fr., $W$. Boone 1296 (MBML, RB). RIO DE JANEIRO: Rio de Janeiro, Corcovado, 11.XI.1883, fl., C.A.W. Schwacke 4793 (M); Rio de Janeiro, Corcovado, 11.XI.1883, fl., J. Nadeaud P04373247 \& P04373248 (P); Rio de Janeiro, Engenho Velho, X.1848, fl., L. Riedel 251 (P); Rio de Janeiro, Reserva Florestal do Jardim Botânico, 19.I.1969, fr., D. Sucre 4475 (RB); Rio de Janeiro, Parque Nacional da Tijuca, estrada de Furnas, próximo à bifurcação com estrada Vista Chinesa, 9.X.1997, fl., D. Araujo 10586 (GUA); Rio de Janeiro, Parque Nacional da Tijuca, estrada de Furnas, próximo a bifurcação com estrada Vista Chinesa, 18.XI.1997, fr., D. Araujo 10597 (GUA); Rio de Janeiro, Alto da Boa Vista, Morro Queimado, 1.X.1987, bt., J.R. Pirani 1989 (GUA); Rio de Janeiro, Cosme Velho, a Laranjeiras, 14.VII.1872, fl., A.F.M. Glaziou 6113 (C, P, RB); Rio de Janeiro, Cosme Velho, a Laranjeiras, 31.X.1872, fl., A.F.M. Glaziou 6115 (P, RB); Rio de Janeiro, estrada da Boa Vista, estrada da Vista Chinesa Km 1, ao lado de um muro com parapeito de canos, 20.X.1997, fr., C.A.L. Oliveira 1380 (GUA); Serra dos Órgãos, fl., A.F.M. Glaziou 1588 (C, P).

Espécie restrita ao ES e RJ, com flores nos meses de julho e outubro, e com frutos em julho e de outubro a novembro. Matayba sylvatica assemelha-se a $M$. cristae e espécies afins por apresentar a nervação inconspícua na face adaxial dos folíolos e reticulação aberta, mas pode ser diferenciada pelos folíolos longamente peciolulados (0,5-0,9 mm compr. em M. sylvatica, contra sésseis em $M$. cristae) e o número de nervuras secundárias em de 7-14 pares (contra 4-8 pares). As domácias, na maioria das vezes ausentes e quando presentes foveoladas nessa espécie, não são salientes na face adaxial dos folíolos enquanto em $M$. cristae, essas estruturas são salientes e urceoladas, e presentes em todos os espécimes analisados.

\section{Táxon excluído}

Matayba talisioides Radlk., in Martius Fl. bras. 13(3): 618. 1900. Tipo: BRASIL. RIO DE JANEIRO. Campo Grande. Mendanha. 28.VIII.1886. A.F.M. Glaziou 11839 (lectótipo P! [aqui designado]; isolectótipos G!, R!).

Matayba talisioides foi publicada na Flora brasiliensis por Radlkofer (1900) baseada apenas em uma coleta (Glaziou 11839) com duplicatas depositadas nos herbários $\mathrm{P}, \mathrm{G}$ e R. No final da descrição, o autor da espécie (1900) aponta que é inexistente a presença de qualquer estrutura reprodutiva (botões, flores ou frutos) nas três duplicatas. Já a semelhança morfológica entre as estruturas vegetativas presentes no material e em diversos outros gêneros de Sapindaceae (espécies de Talisia como exemplo) ou até mesmo de outras famílias relacionadas, fazem com que não seja possível acertar se essa espécie deve ser realmente circunscrita na delimitação do gênero e consequentemente da seção Matayba.

Radlkofer (1934) posicionou Matayba talisioides junto às espécies que possuem folíolos com a rede de nervuras inconspícua na face adaxial, quando secos escurecidos a acinzentados, subglabros em ambas as faces e com as nervuras secundárias em grande número, retilíneas com algumas oblíquas interpostas juntamente a $M$. atropurpurea $(=M$. discolor) e M. sylvatica. Para separar as espécies, Radlkofer (1934) utilizou a consistência dos folíolos (M. atropurpurea, coriáceos; M. sylvatica cartáceomembranáceos e $M$. talisioides, membranáceos) e para diferenciar M. talisioides de M. sylvatica, a forma dos folíolos (lineares contra oblongo- 
lanceolado), o ápice (agudo a obtuso contra levemente obtuso a subemarginado) e a presença de domácias (várias vs. 1-2).

Porém, as características apontadas acima não podem ser utilizadas para separar as espécies e dessa forma, não são suficientes para delimitar este táxon. A decisão sobre a identidade de $M$. talisioides como uma espécie ou como um sinônimo depende na existencia de mais subsídios para elucidar sua situação.

\section{Considerações finais}

Muitas vezes as espécies de Matayba são confundidas principalmente com Cupania (margem dos folíolos geralmente serreada, botões florais completamente fechados e as sépalas livres contra margem dos folíolos geralmente inteiras, botões florais precocemente abertos e sépalas unidas em Matayba). Além disso, muitas espécies referidas nas obras clássicas de Radlkofer $(1879,1900,1934)$ estavam ausentes na maioria dos herbários.

Os caracteres diagnósticos que foram utilizados por Radlkofer (1934) são ainda de extrema importância e neste trabalho foram base para a separação das espécies, porém buscou-se atualizar os conhecimentos e Matayba sect. Matayba conta agora com 17 espécies e apenas $M$. boliviana não apresenta ocorrência em território brasileiro. Outras duas além do Brasil também estão presentes em outros países da América do Sul (M. elaeagnoides ocorre no Brasil, Paraguai e norte da Argentina e $M$. guainensis que ocorre na grande maioria dos países sul-americanos), corroborando dessa maneira a distribuição das espécies desta seção conforme sugerido por Radlkofer (1934).

Os principais caracteres morfológicos utilizados na taxonomia da seção Matayba são com relação aos folíolos e principalmente sua nervação (tipo), com padrões constantes entre as espécies (posição e forma das nervuras secundárias, proeminência e reticulação da nervação como um todo), o indumento de partes vegetativas e reprodutivas das plantas, presença ou ausência de domácias, superfície do epicarpo nos frutos e o tamanho do arilo nas sementes.

Apesar do mesmo número de espécies, algumas alterações taxonômicas foram feitas na presente circunscrição da seção. Duas espécies (M. atropurpurea e M. pallens) e dez formas e subformas foram sinonimizadas. Além disso, M. talisioides foi considerada como uma espécie excluída já que o tipo nomenclatural e sua descrição original não contam com flores e frutos e desta maneira, não apresenta as informações necessárias para sua inclusão na seção. Por outro lado, foram adicionadas duas espécies, M. obovata e M. livescens, esta última, reconhecida previamente por Radlkofer (1934) com uma forma de M. guianensis (M. guianensis f. livescens). Outros avanços alcançados foram os 20 novos lectótipos e um novo neótipo designados.

\section{Agradecimentos}

Os autores deste trabalho agradecem a Laura Simón, as ilustrações botânicas. A Pedro Acevedo-Rodríguez e Genise V. Somner, os valiosos comentários e sugestões. Aos curadores dos herbários que disponibilizaram materiais. E finalmente aos revisores que fizeram as devidas sugestões científicas. Este trabalho foi realizado com apoio e bolsa do CNPq e terminado com o auxílio do Projeto FAPESP 2015/09444-4 e do Projeto REFLORA.

\section{Referências}

Acevedo-Rodríguez, P.; Van Welzen, P.C.; Adema, F. \& Ham, R.W.J.M. van der. 2011. Sapindaceae. In: Kubitizki, K. Flowering plants. Eudicots: Sapindales, Cucurbitales, Myrtaceae. The families and genera of vascular plants. Springer, Berlim. Pp. 357-407.

Acevedo-Rodriguez, P. 2012. Sapindaceae. In: Mota de Oliveira, S. Flora of the Guianas, Fasc. 29. Richmond, Surrey, Royal Botanic Garden, Kew. 196p.

Aublet, F. 1775. Histoire des Plantes de la Guiane Françoise. Vol. 1. Didot jeune, Londres, Paris. $621 \mathrm{p}$.

BFG. 2015. Growing knowledge: an overview of seed plant diversity in Brazil. Rodriguésia 66: 1085-1113.

Brummit, R.K. \& Powell, C.E. (eds.). 1992. Authors of plant names. A list of authors of scientific names of plants, with recommended standard forms of their names, including abbreviations. The international plant names index (2012). Disponível em $<$ http://www.ipni.org $>$. Acesso em 20 maio 2016.

Coelho R.L.G.; Souza, V.C. \& Ferrucci, M.S. 2012. Matayba obovata, a new species of Matayba sect. Matayba (Sapindaceae) from Brazil. Brittonia 64: 43-48.

Coelho, R.L.G.; Souza, V.C. \& Ferrucci, M.S. 2014. Nota sobre Matayba livescens stat. nov. (Sapindaceae, Cupanieae) do litoral brasileiro. Rodriguésia, 65: 711-715. 
Ferrucci, M.S. 1991. Sapindaceae. In: Spichier \& Raven, P.H. (eds.). Flora del Paraguay. Conservatoire et Jardin botaniques de la Ville de Genéve (Genéva). Missouri Botanical Garden, St. Louis. Pp. 18-144.

Ferrucci, M.S. 1998. Flora Fanerogámica Argentina; Família 165 Sapindaceae. Vol. 52. Museo Botânico, IMBIV, Córdoba. Pp. 1-44.

Radlkofer, L. 1879. Sapindaceae. Sitzungsberichte der Mathematisch-Physikalischen Klasse der K.B. Vol. 5. Akademie der Wissenschaften zu München, Munique. Pp. 630-637.

Radlkofer, L. 1895. Sapindaceae In: Engler, A. \& Prantl, K. Die Natürlichen Pflazenfamilien 3: 277-366.
Radlkofer, L. 1892-1900. Sapindaceae. In: Martius, C.F.P. Flora brasiliensis. Leipzig, Munchen, Wien. Vol. 13, pars 3, pp. 225-658.

Radlkofer, L. 1934. Sapindaceae In: Engler, A. \& Diel, L. Das Pflanzenreich Regni Vegetabilis Conspectus 4: 1019-1109.

Thiers, B. [continuously updated]. Index Herbariorum: A global directory of public herbaria and associated staff. New York Botanical Garden's Virtual Herbarium. Disponível em $<$ http://sweetgum.nybg. org/science/ih/>. Acesso em 9 junho 2016.

Somner, G.V. \& Ferrucci, M.S. 2004. A new species of Cupania L. sect. Trigonocarpus (Sapindaceae) from Brazil. Botanical Journal of the Linnean Society 146: 217-221. 